\title{
Człowiek w obliczu epidemii - relacja Tukidydesa i Prokopiusza z Cezarei
}

\section{Wprowadzenie}

W niniejszym artykule zostanie przedstawiony obraz dwóch epidemii, z których pierwsza pojawiła się w Atenach w 430 roku przed Chrystusem, a druga - w Konstantynopolu w 542 roku, oraz wpływu, jaki wywarły na dotknięte tymi chorobami społeczności nie tylko na płaszczyźnie czysto biologicznej, powodując ogromną ilość zgonów, lecz także w wymiarze psychologiczno-socjologicznym, rujnując obyczajową stabilność, jak również szacunek dla prawa i zasad religijnych.

Jakkolwiek wydarzenia te są rozdzielone niemal tysiącleciem rozpiętości czasowej, znalazły paralelne odbicie w dziełach autorów należących do najwybitniejszych przedstawicieli greckiej historiografii antycznej. Tukidydes, otwierający krytyczny i nacechowany racjonalizmem styl narracji historycznej mającej na celu nie tylko przedstawienie zweryfikowanych faktów, lecz także ustalenie ich przyczyn², zawarł w swym dziele Wojna

1 Małgorzata Siwicka, doktor nauk humanistycznych, asystent dydaktyczny w Instytucie Literaturoznawstwa na Wydziale Nauk Humanistycznych KUL; email: msiwicka@kul.lublin.pl; ORCID: 0000-0001-7844-9703.

2 Charakterystykę stylu Tukidydesa i odmienności jego dzieła w relacji do poprzedników, logografów, a potem Herodota przedstawia Romuald Turasiewicz w: Tukidydes, Wojna peloponeska, t. 1, tł. K. Kumaniecki, opr. R. Turasiewicz, s. XXIV-XXX, Wrocław 2004. We współpracy z De Agostini Sp. z o.o., wydanie zaś zostało oparte na publikacji Zakładu Narodowego im. Ossolińskich z roku 1991, Seria II Biblioteki Narodowej nr 225. Zob. też: Literatura Grecji starożytnej, t. 2, red. H. Podbielski, Lublin 2005, s. 22-36. 
peloponeska szczegółowy opis zarazy, jaka dotknęła Ateny w drugim roku konfliktu ze Spartą i stała się przyczyną śmierci między innymi wybitnego polityka ateńskiego Peryklesa. Opis ten od strony literackiej maluje dramatyczny obraz zagłady wyniszczającej całą społeczność, z drugiej natomiast pozostaje obiektywnym, niemal beznamiętnym klinicznym sprawozdaniem z przebiegu choroby oddanym przy użyciu fachowych terminów lekarskich szkoły hipokratejskiej ${ }^{3}$. W dodatku opisu tego dokonuje autor, który był nie tylko obserwatorem, lecz i uczestnikiem przedstawianych wydarzeń - chociaż sam padł ofiarą tej straszliwej choroby, udało mu się przeżyć. Dzieło Tukidydesa cieszyło się ogromną popularnością i w czasach hellenistycznych, i w okresie cesarstwa rzymskiego, było czytane i komentowane zarówno przez autorów greckich, jak i łacińskich ${ }^{4}$.

Bizancjum, które zachowało ciągłość greckiej tradycji językowo-literackiej od epoki klasycznej praktycznie do czasu swego upadku, również przechowało w swej tradycji historiograficznej znajomość dzieła Tukidydesa ${ }^{5}$ do czasów późnego średniowiecza i przekazało ją Europie Zachodniej.

3 Klaus Weidauer w swej pracy Thukydides und die Hippokratischen Schriften, Der Einfluss der Medizin auf Zielsetzung und Darstellungsweise des Geschichtswerks (Heidelberg 1954) stawia tezę o stosowaniu przez Tukidydesa terminologii hipokratejskiej nie tylko przy opisie zarazy ateńskiej, ale w wielu innych sytuacjach, na przykład gdy przedstawia przyczyny wojny. O terminologii medycznej w opisie zarazy Tukidydesa, zob. D.L. Page, Thucydides' Description of the Great Plague at Athens, ,The Classical Quarterly, New Series" 3/4 (1953) s. 97-119; A. Parry, The language of Thucydides' description of the Plague, „Bulletin of the Institute of Classical Studies” 16/1 (1969) s. 106-118.

4 Najbardziej znane w literaturze łacińskiej parafrazy i przeróbki opisu zarazy znajdujemy w filozoficznym poemacie Lukrecjusza De rerum natura (VI 1090-1102, 1138 1144), w Metamorfozach Owidiusza (VII 523-613). Wergiliusz wykorzystuje tę relację przy opisie zarazy bydła w Georgikach (III 440-565).

5 Por. Tukidydes, Wojna peloponeska, t. 1, s. CXXXVIII: „Popularność Tukidydesa sięga głęboko w okres bizantyński, greckie średniowiecze. Dość powiedzieć, że jak o Homerze mówiono po prostu «poeta» bez wymieniania «na próżno» jego imienia, jak o Arystotelesie mówiono «filozof», o Demostenesie «mówca», tak o Tukidydesie - «historyk»". Nie tylko Prokopiusz studiował i naśladował Tukidydesa. Podobnie czynili historyk Jan Epifanijczyk (VI/VII wiek), opisując dzieje zmagań bizantyńsko-perskich, oraz Teofilakt Symokatta (VII wiek), który korzystał z całej historiografii greckiej, z dzieł Herodota, Tukidydesa, Ksenofonta i późniejszych historyków epoki cesarstwa. Nawet historycy jeszcze bardziej odlegli czasowo od epoki klasycznej, tacy jak Jan Kantakuzenos (XIV wiek), Laonikos Chalkokondyles (XV wiek), Michał Kritobulos (XV wiek), Wojne peloponeska Tukidydesa traktowali jako wzór i punkt odniesienia, używając jego metodologii, naśladując styl, słownictwo, sposób ujęcia materiału. „Warto dodać, iż znany teo$\log$ i filolog Maksimos Planudes (1255-1305) pisał komentarze do Tukidydesa, natomiast 
Jednym z najznakomitszych historyków greckich zamykających epokę starożytną jest Prokopiusz z Cezarei (VI wiek), którego dzieła stanowią główne źródło informacji o panowaniu cesarza Justyniana ${ }^{6}$. Podobnie jak Tukidydes Prokopiusz był aktywnym uczestnikiem wielu wydarzeń przedstawianych w swym najważniejszym dziele, Historii wojen. Pozostając w bliskim otoczeniu cesarza, pełnił ważne urzędy państwowe, a także towarzyszył Belizariuszowi jako doradca i sekretarz podczas jego wypraw przeciwko Wandalom i Gotom. Podczas epidemii, najprawdopodobniej dżumy, która wybuchła w Konstantynopolu w 542 roku przebywał w tym mieście i jakkolwiek nie wspomina, aby sam zapadł na tę chorobę, poznał dokładnie jej przebieg i skutki, jakie ze sobą przyniosła.

Prokopiusz, podobnie jak wszyscy, którzy planowali karierę w administracji państwowej, otrzymał staranne wykształcenie klasyczne, znał też język łaciński, konieczny do studiów prawniczych. Znajomość greki klasycznej wśród warstw wykształconych Konstantynopola była powszechna nawet w czasach średniowiecza ${ }^{7}$, co umożliwiało zachowanie ciągłości literackiej i kulturowej pomimo upływu kilkuset wieków.

Prokopiusz świetnie znał całą literaturę starogrecką począwszy od Homera aż do historiografów włącznie. Oczytany w dziełach Herodota, Tukidydesa, Polibiusza naśladował ich w stylu i kompozycji, za wzór jednak obrał sobie przede wszystkim Wojne peloponeska Tukidydesa. Posługiwał się klasycznym językiem attyckim tak w słownictwie i zwrotach, jak w całych frazach. Przenosił do swej Historii wojen pełne opisy z Tukidydesa, adaptując je do własnych potrzeb kompozycyjnych. Mimo gruntownej znajomości greki kla-

wybitny filolog Tomasz Magister (XIII/XIV w.), znany pod imieniem mnicha Teodulosa, autor licznych traktatów teologicznych, filozoficznych i retorycznych, ułożył Słownik rzeczowników i przymiotników, w którym obok innych pisarzy greckich V i IV w. p.n.e. uwzględnił w dużej mierze dzieło Tukidydesa" (Tukidydes, Wojna peloponeska, t. 1, s. CXXXIX).

6 Zob. J.A. Evans, Justinian and the Historian Procopius, ,Greece \& Rome” 17/2 (1970) s. 218-223.

7 Kwestia popularności Tukidydesa w kulturze bizantyńskiej, zwłaszcza w wiekach od VIII do XIII, nie wszystkim badaczom wydaje się tak oczywista. Począwszy od wieku VIII, następuje odejście od studiowania dzieł Tukidydesa, przede wszystkim ze względu na wysoki stopień trudności języka, jakiego używał, a także ze względu na odmienne warunki polityczne, w jakich działał i pisał, które nie znajdowały swego odbicia w realiach cesarstwa doby Justyniana. Szczegółowe omówienie tego zjawiska możemy znaleźć w artykule: S. Kennnedy, A Classic Dethroned: The Decline and Fall of Thucydides in Middle Byzantium, „Greek, Roman and Byzantine Studies” 58 (2018) s. 607-635. 
sycznej dopuszczał się pewnych uchybień na rzecz języka współczesnego, widocznych w stosowaniu składni przyimków czy trybu życzącego, który wyszedł wówczas z użycia ${ }^{8}$.

Tak jak opis zarazy Tukidydesa otwiera, a jednocześnie stanowi wzór dla kolejnych tego typu opisów pojawiających się w literaturze historycznej czy nawet w poezji okresu starożytnego ${ }^{9}$, tak opis zarazy dokonany przez Prokopiusza ten szereg zamyka, pozostając wyraźnym odbiciem

$8 \quad$ O. Jurewicz, Historia literatury bizantyńskiej. Zarys, Wrocław 1984, s. 40. Podobną opinię o stylu historiografii Prokopiusza wyraża Turasiewicz: „Prokopiusz [...] w swej Historii wojen nie tylko wzorował się na stylu Tukidydesa, od którego przejmował całe wyrazy i zwroty, a nawet całe opisy, ale też korzystał z jego metodologicznych zasad" (Tukidydes, Wojna peloponeska, t. 1, s. CXXXVII). Na temat dzieł i specyfiki stylu Prokopiusza zob. też: J.A. Evans, Justynian i imperium bizantyńskie, tł. B. Godzińska, Warszawa 2008, s. 159-161. „Prokopiusz należał do tej szkoły, która wzorowała swoje prace na klasycznych historykach - Herodocie i Tukidydesie (V w. p.n.e.). Mogło się wydawać, że historycy ci pisali dla czytelników żyjących tysiące lat przed ich epoką. Pojęcia, których mógł nie zrozumieć Grek poganin z czasów klasycznych, były poprzedzane zwrotem «tak zwany» lub objaśniane. Chrześcijaństwo uważano za religię obcą, z którą czytelnicy nie byli obznajomieni. W efekcie wielu współczesnych czytelników spekuluje, że Prokopiusz był poganinem, lecz pojawiają się tutaj pewne wątpliwości, czy jego przypuszczalne pogaństwo nie było tylko pozą literacką". (Tukidydes, Wojna peloponeska, t. 1, s. 160). Por. Jurewicz, Historia literatury bizantyńskiej, s. 40: „Styl Historii wojen Prokopiusza oraz innych jego pism odznacza się pełną przejrzystością, jest potoczysty, wolny od nadmiaru retoryki. Głębokie wykształcenie klasyczne Prokopiusza, podziw dla wielkiej przeszłości Grecji starożytnej widać także w pomieszaniu dwóch światów myśli i ideologii - świata pogańskiego i świata chrześcijańskiego". Nieco odmienną opinię na temat korzystania przez Prokopiusza z tradycji klasycznej, Herodota, Tukidydesa i innych autorów, zob. A. Kaldellis, Procopius of Caesarea: Tyranny, History and of Philosophy at the End Antiquity, Philadelphia 2004 (zwł. Chapter 1: Classicism and Its Discontents, s. 17-61). Autor upatruje w stylu historiografii Prokopiusza nie tylko naśladowanie wzorców klasycznych wynikające $\mathrm{z}$ podziwu dla wymienionych autorów, ale celowe i twórcze ich przekształcanie oraz wykorzystanie w celu przekazania pewnych myśli i poglądów, których nie mógł wypowiedzieć bezpośrednio.

9 Opis zarazy z pierwszej księgi Iliady Homera oczywiście poprzedza dzieło Tukidydesa, ale jest on raczej opisem zemsty Apollona za znieważenie kapłana Chryzesa i nie zawiera praktycznie żadnych szczegółowych informacji o samej chorobie poza wzmianką o wielkiej liczbie zgonów oraz śmierci ludzi i zwierząt. Można jednak odnaleźć próby ustalenia, jaką chorobę opisał Homer: Zob. G. Tsoucalas - K. Laios - M. Karamanou - G. Androutsos, Demystifying the epidemic among Achaens during the Trojan War, „Le infezioni in Medicina" 22/4 (2014) s. 342-348. Autorzy sugerują, iż mogła być to choroba wywołana przez wirusa z rodzaju Alphavirus. 
pierwowzoru z V wieku przed Chrystusem, zwłaszcza na płaszczyźnie kompozycji treści, a jednocześnie zachowując oryginalność przekazu (nie dotyczy tej samej choroby, jak też jej przebieg ma miejsce w odmiennych warunkach $)^{10}$. Bardziej szczegółowe omówienie i porównanie tych dwóch relacji zostanie przedstawione $\mathrm{w}$ dalszej części niniejszego artykułu ${ }^{11}$.

Ponieważ przedmiotem przedstawianej tu analizy są teksty literackie, celem tego opracowania nie będzie ustalenie, jaką znaną dzisiaj chorobę o charakterze epidemicznym opisują Tukidydes czy Prokopiusz. Pytanie to stawiało sobie wielu badaczy i w niektórych dawniejszych opracowaniach, zarówno z dziedziny historii medycyny, jak i filologii formułowano dość zdecydowane odpowiedzi, najczęściej utożsamiając obydwie epidemie z dżumą lub z tyfusem w przypadku Aten. Wybrane pozycje dotyczące medycznego aspektu tego zagadnienia zostały umieszczone w przypisach $^{12}$. Obecnie historycy, lekarze czy inni zainteresowani tematem epide-

10 Zob. A.W. Gomme, A Historical Commentary on Thucydides, t. 2, Oxford 1966, s. 146. Autor nazywa opis Prokopiusza ,imitation”, chociaż przyznaje mu sporo oryginalności, zarzucając jednocześnie wprowadzanie niepotrzebnych dłużyzn.

11 W przeciągu wieków pomiędzy wojną peloponeską a czasami Justyniana na terenie Cesarstwa Rzymskiego pojawiały się oczywiście inne epidemie, jak na przykład w 65 roku, za czasów Nerona, o której wspominają Swetoniusz i Tacyt, czy ta w latach 165180 za czasów Antoninów, której ofiarą padł cesarz Marek Aureliusz, opisywana przez Galena. Żaden autor ani historyk, ani lekarz jednak nie pozostawił tak obszernych i interesujących relacji, jak Tukidydes i Prokopiusz.

12 Epidemia ateńska była identyfikowana z wieloma chorobami, na przykład z odrą. Zob.: J.F.D Shrewsbury, The Plague of Athens, „Bulletin of the History of Medicine” 24 (1950) s. 1-25. Najwięcej zwolenników znalazła teoria tyfusu, którą propagował Raymund Crawfurd. Zob. R. Crawfurd, Plague and Pestilence in Literature and Art, Oxford 1914. Tę interpretację przyjął znakomity znawca dzieła Tukidydesa Arnold W. Gomme. W swoim komentarzu historycznym do tego utworu zamieszcza obszerny passus dotyczący argumentów na rzecz tej właśnie choroby. Zob. Gomme, A Historical Commentary on Thucydides, t. 2, s.150-153. Kwestia identyfikacji zarazy ateńskiej pozostaje wciąż tematem badań epidemiologów. Niektóre z ich współczesnych badań zdają się potwierdzać teorię tyfusu. Więcej szczegółów na ten temat można znaleźć na przykład w: D.M. Morens - R.J. Littman, Epidemiology of the Plague of Athens, ,Transactions of the Philological Association” 122 (1992) s. 271-304; R.J. Littman, The Plague of Athens: Epidemiology and Paleopathology, „Mount Sinai Journal of Medicine” 76/5 (2009) s. 456-467; M.J. Papagrigorakis - Ch. Yapijakis - Ph.N. Synodinos - E. BaziotopoulouValavani, DNA examination of ancient dental pulp incriminates typhoid fever as a probable cause of the Plague of Athens, „International Journal of Infectious Diseases” 10 (2006) s. 206-214. Inni badacze jednak sugerują, iż był to przypadek jakieś gorączki wirusowej. Zob. P.E. Olson, The Thucydides Syndrome: Ebola Déjà vu? (or Ebola Reemergent?), 
mii w czasach starożytnych unikają identyfikowania, zwłaszcza epidemii ateńskiej, z jakąkolwiek chorobą o charakterze epidemicznym występującą obecnie. Jak pisze Turasiewicz: „Prawie nad wszystkim, co napisano dotychczas na temat ateńskiej zarazy, zaciążył pogląd, iż musiała to być jakaś choroba, którą dziś znamy. Wcale tak jednak być nie musi, a nawet byłoby to mało prawdopodobne"13.

Co do identyfikacji epidemii z czasów Justyniana, można pokusić się o bardziej wiarygodne ustalenia oparte nie tylko na opisie przekazanym przez Prokopiusza, ale i na najnowszych badaniach DNA, które potwierdzają, iż mieszkańców Konstantynopola dotknęła epidemia dżumy ${ }^{14}$.

Celem niniejszego opracowania jest przede wszystkim przedstawienie postaw i działań ludzkich w sytuacji skrajnego śmiertelnego zagrożenia, gdy człowiek traci całkowicie kontrolę nad własnym losem, zarówno w wymiarze indywidualnym, jak i społecznym, a także zestawienie i zaprezentowanie podobieństw oraz różnic $\mathrm{w}$ dwóch wymienionych opisach dotyczących takich właśnie sytuacji. Obydwaj autorzy przekazują nam obraz skutków, jakie epidemia może wywołać w psychice człowieka, a także w szerszym wymiarze w relacjach międzyludzkich, wpływając na losy nie tylko jednostek, lecz i całych organizmów państwowych.

Chociaż, jak już zaznaczono wyżej, Prokopiusz wzorował swą relację na opisie Tukidydesa, pominięte zostaną szczegółowe analizy gramatyczno-syntaktyczne obydwu tekstów, a raczej porównanie zostanie przeprowadzone na płaszczyźnie kompozycji treściowej, dyspozycji materiału, sposobu prowadzenia narracji, użycia pewnych toposów literackich oraz

„Emerging Infectious Disease” 2 (1996) s. 1-23; G.T. Papanikos, Thucydides and the Synchronous Pandemic, „Athens Journal of History” 7/1 (2021) s. 73.

13 Turasiewicz (Tukidydes, Wojna peloponeska, s. LXXIII) referuje w tym miejscu poglądy badaczy brytyjskich (J.C.F. Poole - A.J. Hollday, Thucydides and the Plague of Athens, „Classical Quarterly N.S.” 29 (1979) s. 282-297).

${ }_{14}$ Zob. M. Feldman et al. A High-Coverage Yersinia pestis Genome from a SixthCentury Justinianic Plague Victim, „Molecular Biology and Evolution” 33/11 (2016) s. 2911-2923. Autorzy potwierdzają obecność genomu bakterii Yersinia pestis na szkieletach znalezionych w południowych Niemczech, w pobliżu Monachium, pochodzących z VI wieku po Chrystusie. Najprawdopodobniej dżuma dotarła do Italii, a stamtąd do Europy Zachodniej wraz z wojskami Belizariusza. Zob. też: D. Gutsmiedl-Schümann, et al., Digging up the plague: A diachronic comparison of aDNA confirmed plague burials and associated burial customs in Germany, ,Praehistorische Zeitschrift” 92/2 (2018) s. 408-416; M. McCormick, Toward a Molecular History of the Justinianic Pandemic, w: Plague and the End of Antiquity. The Pandemic of 541-750, red. L.K. Little, Cambridge 2007, s. 290-312. 
ewentualnych odniesień i komentarzy obydwu autorów do opisywanych wydarzeń. Jak zauważa Ewa Bugaj:

Stwierdzić można, że historyczne opisy plag cechuje zawsze pewien stopień stylizacji, pojawiają się toposy przydające narracji efektów literackich, aczkolwiek studia nad owymi źródłami przekonują badaczy, że oprócz nieuniknionej i celowej stylizacji, zasadniczo relacjonują one prawdopodobny przebieg wydarzeń mających najczęściej podobnie rozgrywać się podczas wybuchu epidemii ${ }^{15}$.

Pomimo powyższych założeń nie sposób pominąć w tym miejscu informacji związanych z objawami i przebiegiem choroby. Miały one bowiem znaczący wpływ na zachowania zarówno chorych, jak i ich bliskich, a także na działania, jakie podejmowano i w związku z przebiegiem samej choroby, a także wtedy, gdy usiłowano zmierzyć się z jej śmiertelnymi skutkami.

\section{Wiarygodność autorów}

Obydwie te relacje stanowią wiarygodny przekaz informacji z miejsca wydarzeń przez osoby, które w tych zdarzeniach uczestniczyły. Tukidydes nie tylko przebywał w Atenach podczas tych dramatycznych wydarzeń, ale sam również zapadł na tę tajemniczą chorobę, tak więc jego relacja pozostaje jedyną w swoim rodzaju - jest ona przekazem przeżyć bezpośredniego uczestnika dramatu, osoby, która sama doświadczyła opisywanej sytuacji w jej najboleśniejszym wymiarze. Nie podając konkretnej nazwy

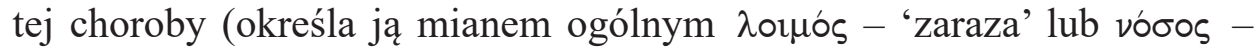
'choroba'), stwierdza:

O chorobie tej niechaj mówi każdy - czy to lekarz, czy laik - według swego uznania [...]; ja ograniczę się do opisu jej przebiegu i podam oznaki, po których będzie można tę chorobę rozpoznać, jeśliby się jeszcze kiedyś pojawiła; sam bowiem chorowałem na nią i widzialem innych, którzy na nią zapadli ${ }^{16}$.

15 Zob. E. Bugaj, Zaraza w świecie rzymskim w czasach Antoninów, w: Epidemie, klęski, wojny, Funeralia Lednickie, Spotkanie 10, red. W. Dzieduszycki - J. Wrzesiński, Poznań 2008, s. 117.

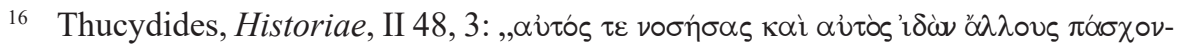
$\tau \alpha \varsigma^{\prime \prime}$, tł. Kumaniecki, s. 157. Relacja Tukidydesa jest pierwszym w pełni wiarygodnym, historycznym, pochodzącym ,z pierwszej ręki” zapisem epidemii dokonanym przez oso- 
Prokopiusz, podobnie jak Tukidydes, jest zarówno świadkiem, jak i uczestnikiem przedstawianych wydarzeń, ponieważ przebywał podczas epidemii w Konstantynopolu. W odróżnieniu od Tukidydesa sam nie chorował, o czym zapewne nie omieszkałby wspomnieć: „W drugim roku [swego trwania, epidemia] dotarła w środku wiosny do Bizancjum, gdzie i mnie zdarzyło się wtedy przebywać" ${ }^{17}$.

Chociaż obydwaj historycy skupiają swą uwagę przede wszystkim na tych wydarzeniach, które miały miejsce w terenie miejskim (Ateny i Konstantynopol), wskazują też na katastrofalne skutki, jakie te epidemie przyniosły w wymiarze państwowym, zmieniły bowiem zarówno losy wojny peloponeskiej ${ }^{18}$, a co za tym idzie, niemal całej Hellady, jak i losy wojny, jaką prowadziło Bizancjum z władcą perskim Chosroesem ${ }^{19}$. Prokopiusz wspomina też o tragicznych skutkach ekonomicznych, jakie spowodowała epidemia na terenach rolniczych, co pociągnęło za sobą kryzys gospodarczy w całym cesarstwie ${ }^{20}$.

\section{Okoliczności wybuchu epidemii, jej zasięg i czas trwania}

Według przekazu Tukidydesa zaraza pojawiła się w Attyce i zaraz potem w Atenach w drugim roku wojny peloponeskiej prowadzonej między Atenami i Spartą, która to wojna objęła swym zasięgiem niemal całą Helladę. Pierwsza fala epidemii trwała od wiosny 430 do końca 429 roku,

bę, która sama przeżyła chorobę. Tłumaczenie tekstu Tukidydesa podaję w przekładzie Kazimierza Kumanieckiego, ewentualne zmiany bądź uwagi do tego tłumaczenia zaznaczam w przypisach. Wszystkie podkreślenia w cytatach polskich i greckich pochodzą od autorki artykułu

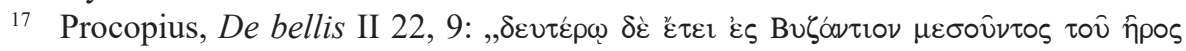

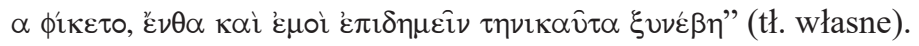

18 Thucydides, Historiae, I 23, 3: „,...] Niezwykle silne trzęsienia ziemi na dużych obszarach, zaćmienia słońca, zdarzające się częściej, niż to za z dawniejszych czasów wspominano, wielkie susze i spowodowane przez nie klęski głodowe, a przede wszystkim zaraza, która w poważnym stopniu spustoszyła i częściowo zniszczyła Helladę - wszystko to szło równocześnie z tą wojną", tł. Kumaniecki, s. 23.

19 Procopius, De bellis II 24, 8: „,Chosroesa] i całą armię perską zaatakowała zaraza. Dlatego też chcieli zawrzeć pokój z Rzymianami”, tł. własne.

20 Zagadnienie to zostanie omówione w punkcie IX niniejszego artykułu ( Wptyw epidemii na życie społeczne i gospodarcze). 
powróciła zimą 427/426 i trwała do zimy 426/425²1. Epidemia miała swój początek w Etiopii, a następnie przewędrowała na tereny Egiptu, Libii i państwa perskiego, wkraczając tym samym do Azji Mniejszej. Stamtąd najprawdopodobniej przedostała się na leżącą w pobliżu wybrzeży Azji Mniejszej wyspę Lemnos i na inne wyspy oraz dotarła do Aten i Attyki, gdzie siała największe spustoszenie. Spowodowane to było w dużej mierze przygotowaniami Ateńczyków do wojny ze Spartą. Perykles, przewidując rychłe wkroczenie do Attyki armii lacedemońskiej, która miała palić i niszczyć tereny wiejskie, nakłonił mieszkańców terenów wiejskich do ewakuacji. Chociaż niechętnie, przenieśli się oni do samych Aten, Pireusu oraz w obręb Długich Murów ${ }^{22}$. Nieuniknionym skutkiem takiej sytuacji było niebywałe wcześniej zagęszczenie ludności na niewielkim, zamkniętym obszarze, w gorącej porze letniej, gdzie panowały koszmarne warunki bytowe, przede wszystkim sanitarne. Obok stałych mieszkańców miasta, którzy zamieszkiwali własne siedziby, przybysze żyli w skleconych naprędce lepiankach albo na terenach świątyń ${ }^{23}$.

Epidemia zaatakowała najpierw mieszkańców Pireusu, uważano nawet, że to Lacedemończycy celowo zatruli tam studnie ${ }^{24}$, ale sam

${ }^{21}$ Por. B. Bravo - M. Węcowski - E. Wipszycka - A. Wolicki, Historia Starożytnych Greków, t. 2: Okres Klasyczny, Warszawa 2009, s. 169.

22 Już w czasie pierwszej inwazji, w 431 roku przed Chrystusem Lacedemończycy nie podchodzili bezpośrednio pod mury Aten, ale plądrowali Attykę, otaczając Ateny łukiem w promieniu ok. $10 \mathrm{~km}$. „Dystans był dobrze przemyślany: Ateńczycy widzieli z miasta skutki działalności wroga (zwłaszcza łuny pożarów), równocześnie jednak odległość była zbyt duża, by zaskoczyć przeciwnika zbrojnym wypadem" (Bravo -Węcowski - Wipszycka - Wolicki, Historia Starożytnych Greków, t. 2, s. 165). Zob. też: Thucydides, Historiae II 13, 1-2; II 14, 1-2 oraz II 17, 1-4: „Kiedy zaś przybyli do miasta, niewielu tylko znalazło mieszkanie czy schronienie u przyjaciół czy krewnych; większość zajęła nie zabudowane place miejskie, świątynie i kaplice herosów z wyjątkiem akropoli, świątyni eleuzyńskiej i innych nielicznych świątyń, które były mocno zamykane; osiedlili się również z konieczności na obszarze zwanym Pelasgikon, u stóp akropoli [...]. Wielu schroniło się nawet w wieżach miejskich, a ponadto gdzie kto mógł; miasto było za szczupłe, by wchłonąć wszystkich przybyszów. Później zamieszkali także obszar długich murów, podzieliwszy go między siebie, oraz wielką część Pireusu”, tł. Kumaniecki, s. 135-136.

23 Por. Thucydides, Historiae II 52, 1-2.

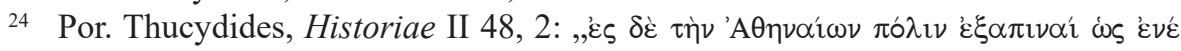

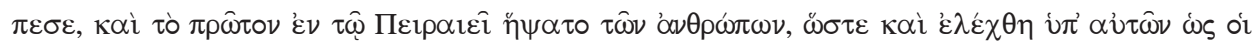

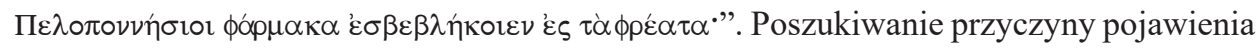
się epidemii oraz oskarżanie wybranych grup ludzkich, które budziły negatywne emocje, o jej wywołanie są jednym ze stałych motywów, które pojawiają się w starożytnych relacjach dotyczących różnych epidemii. Zob. R.P. Duncan-Jones, The Impact of the Antonine 
Tukidydes nie podziela tego zdania, przytacza jedynie szerzące się wówczas pogłoski. Następnie choroba przeniosła się do górnego miasta i wtedy śmiertelność jeszcze wzrosła ${ }^{25}$. Tukidydes nie podaje dokładnej liczby osób, które zmarły wskutek zarazy w samym mieście, podkreśla jedynie, że „nigdzie jednak nie wspominano o tak wielkim nasileniu epidemii i o tak wielkiej śmiertelności wśród ludzi jak w Attyce"26. Dodatkowo działania wojenne prowadzone przez Ateńczyków przyczyniły się do rozprzestrzeniania się choroby na kolejne obszary Hellady. Wojsko ateńskie, które walczyło z najeźdźcą poza murami miasta, przenosiło zarazę daleko poza teren Attyki. Armia pod dowództwem Hagnona, która oblegała miasto Potidaję w Tracji, straciła ponad jedną trzecią zasobów ludzkich i musiała wycofać się do Aten ${ }^{27}$. Podczas drugiej fali zarazy straty również były ogromne:

Następnej zimy po raz drugi wybuchła w Atenach zaraza. I przedtem nie wygasła ona zupełnie, lecz nasilenie jej było mniejsze. Za drugim razem trwała nie mniej niż rok, a za pierwszym nawet dwa lata; żadna klęska nie podkopała bardziej sily Aten. Zginęło bowiem wskutek zarazy nie mniej niż cztery tysiące czterystu powołanych pod broń hoplitów i trzystu jeźdźców oraz mnóstwo ludności ${ }^{28}$.

Sytuacja społeczeństwa Bizancjum w czasie wybuchu epidemii różniła się znacznie od sytuacji Ateńczyków, zagrożonych bezpośrednio działaniami wojennymi, chociaż zaraza pojawiła się tam w momencie, gdy ce-

Plague, „Journal of Roman Archeology” 9 (1996) s. 112-115. Tukidydes jednak dystansuje się od przypisywania Peloponezyjczykom, jako wrogom Aten, odpowiedzialności za wybuch epidemii. Zob. Papanikos, Thucydides and the Synchronous Pandemic, s. 79-20; H.D. Westlake, ,, AEГETAI” in Thucydides, „Mnemosyne” 30/4 (1977) s. 347.

25 Por. Thucydides, Historiae II 48, 2.

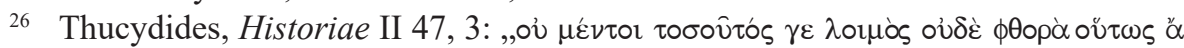

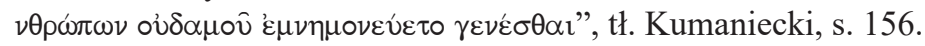

27 Por. Thucydides, Historiae II 58, 2-3: „Lecz nie udało im się zająć miasta ani inne przedsięwzięcia nie zostały uwieńczone sukcesem odpowiadającym przygotowaniom, zaraza bowiem dała się dotkliwie we znaki Ateńczykom wyniszczając armię do tego stopnia, że nawet wysłane poprzednio wojsko, będące dotychczas w doskonałym zdrowiu, zaraziło się od żołnierzy Hagnona. [...] Hagnon powrócił z flotą do Aten, straciwszy w skutek zarazy w okresie mniej więcej czterdziestodniowym tysiąc pięciuset hoplitów z ogólnej liczby czterech tysięcy", tł. Kumaniecki, s. 163-164.

28 Thucydides, Historiae III 87, 1-3, tł. Kumaniecki, s. 272. 
sarstwo prowadziło wojnę, i to na kilku frontach ${ }^{29}$. Konstantynopol nie był bezpośrednio narażony na skutki oblężenia bądź wzmożoną migrację ze wsi do miasta, jak to miało miejsce w Atenach, w sytuacji opisanej przez Tukidydesa. Problemy, z jakimi musiały zmagać się wojska Belizariusza, nie dotknęły bezpośrednio mieszkańców Konstantynopola, ale w 540 roku wkraczają na Bałkany plemiona Hunów i Słowian, które również zaczynają zagrażać bezpieczeństwu miasta. Dlatego też pojawienie się epidemii w 541 roku jesienią w Egipcie, a wiosną następnego roku w stolicy Cesarstwa przyczyni się w znacznym stopniu do spotęgowania wszelkiego rodzaju problemów, z jakimi spotyka się społeczeństwo prowadzące walki jednocześnie na kilku frontach. Epidemia okazuje się bardziej nieubłagana niż ta, która dotknęła Ateńczyków - powraca cyklicznie aż do końca VI wieku, wygasa właściwie dopiero w VIII wieku ${ }^{30}$.

Prokopiusz przedstawia szczegółowo wędrówkę epidemii. Zaczęła się od Egipcjan mieszkających w Peluzjum ${ }^{31}$, skąd rozwijała się dwiema drogami: jedną w kierunku Aleksandrii i dalszych części Egiptu, drugą w kie-

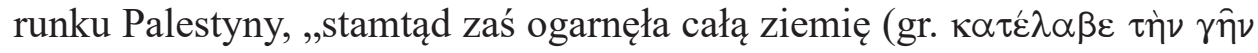
$\sigma u ́ \mu \pi \alpha \sigma \alpha \nu)$ posuwając się nieustannie do przodu i wędrując w stosownym

29 W Italii od 535 roku działania wojenne przeciwko Ostrogotom prowadzi Belizariusz, który pomimo odniesionego tam sukcesu zostaje oskarżony o zdradę i zdymisjonowany właśnie w 542 roku. Dwa lata później ponownie zostaje wysłany przez cesarza do Italii, gdzie w międzyczasie doszło do buntu Ostrogotów, ale armia, jaką zabiera, jest znacznie mniejsza z powodu braku nowych rekrutów, których nie jest w stanie dostarczyć zdziesiątkowana przez zarazę ludność. W dodatku wśród tych, których prowadzi na kolejną wyprawę italską, znajdują się również osoby dotknięte zarazą, skutkiem czego wojsko Belizariusza nie tylko nie jest w stanie prowadzić skutecznych operacji wojskowych, ale staje się „nośnikiem” epidemii w całej Italii. Zaangażowanie militarne Cesarstwa na Zachodzie wykorzystuje władca perski Chosroes, który zaczyna ofensywę w Mezopotamii w 540 roku, następnie zajmuje i pustoszy Antiochię oraz pali i niszczy inne miasta. Persowie dążą również do odebrania Bizantyńczykom terenów kaukaskich zamieszkiwanych przez chrześcijan i osiągnięcia dostępu do Morza Czarnego. Zob. Świat Bizancjum, t. 1: Cesarstwo Wschodniorzymskie 330-641, red. C. Morrisson, tł. A. Graboń, Kraków 2007, s. 41-43; Evans, Justynian i imperium bizantyńskie, s. 19-21, 53-56.

30 Epidemia dżumy w czasach Justyniana nie była jedyną epidemią, jaka dotknęła i osłabiła Cesarstwo w latach jego panowania. Zob. P. Horden, Mediterranean Plague in the Age of Justinian, w: The Cambridge Companion to the Age of Justynian, red. M. Maas, Cambridge 2005, s. 525-526.

31 Zob. C. Tsiamis - E. Poulakou-Rebelakou - G. Androutsos, The Role of the Egyptian Sea and Land Routes in the Justinian Plague: The Case of Pelusium, w: Medicine and Healing in the Ancient Mediterraneans, red. D. Michaelides, Oxford - Philadelphia 2014, s. 334-337. 
po temu czasie" 32. Zauważa też, że „,zaczynała się zawsze na wybrzeżu i stamtąd właśnie posuwała się w głąb lądu" "33, co odpowiadałoby wędrówce wzdłuż morskich szlaków handlowych ${ }^{34}$, ,nie rzucając swej niszczycielskiej siły na nikogo w sposób przypadkowy, ale rozlała się w różnych kierunkach aż po krańce zamieszkałego świata"35.

Podkreślając jeszcze bardziej i tak zrozumiały tragizm sytuacji, stwierdza, że ,z powodu zarazy uległy wyniszczeniu niemal wszystkie istnienia ludzkie" ${ }^{36}$. Choroba atakowała też o różnych porach roku oraz na każdym terenie, nikt również, niezależnie od wieku, płci, stanu zdrowia nie pozostawał bezpieczny.

Prokopiusz zauważa, iż uwzględnienie czynników wymienionych wyżej, a ponadto trybu życia, naturalnych przyzwyczajeń, które odgrywały wielką rolę w terapii innych chorób, w przypadku tej epidemii nie miało najmniejszego znaczenia ${ }^{37}$. Wędrówkę epidemii odmalowuje Prokopiusz niezwykle dramatycznie, nadając chorobie niemal antropomorficzny wymiar - nie oszczędzała ona żadnego skrawka ziemi, ,jakby bojąc się, że umknie jej jakiś zakątek. Nie ominęła bowiem żadnej wyspy ani groty, ani grzbietu górskiego zamieszkałego przez ludzi"38.

Zaraza przybiera u niego postać straszliwego egzekutora wymierzającego wszystkim taką samą karę, dokładnie i precyzyjnie określającego

32 Procopius, De bellis II 22, 6, tł. własne. Określenie „cała ziemia” jest oczywiście retoryczną przesadą. Epidemia przeszła do Syrii i ogarnęła kolejne tereny Azji Mniejszej, Bałkanów i zachodniej Europy.

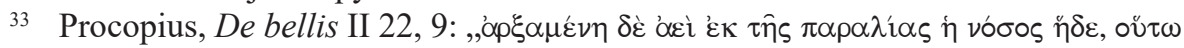

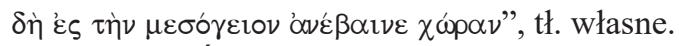

34 Por. Świat Bizancjum, t. 1, s. 42. Zob. też M. McCormick, The origins of the European economy: Communications and commerce, c. $300-$ c. 900, Cambridge 2001, s. 596. Por. Bugaj, Zaraza w świecie rzymskim w czasach Antoninów, s. 118: „Generalnie w obrębie basenu Morza Śródziemnego kierunek rozprzestrzeniania się chorób ze wschodu na zachód znajduje też potwierdzenie w regularnych ruchach statków z towarami przemieszczającymi się najintensywniej ze wschodu na zachód, i to głównie wiosną oraz latem”.

35 Procopius, De bellis II 22, 7, tł. własne.

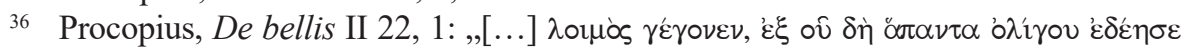

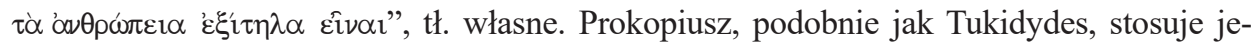
den z popularniejszych toposów literackich występujący właściwie we wszystkich źródłach historycznych dotyczących epidemii, a mianowicie emfatyczne podkreślenie zasięgu, rozmiaru i śmiertelnych skutków choroby epidemicznej przewyższającej wszystkie inne, jakie kiedykolwiek się pojawiły. Zob. Bugaj, Zaraza w świecie rzymskim w czasach Antoninów, s. 118; Duncan-Jones, The Impact of the Antonine Plague, s. 112-115.

37 Por. Procopius, De bellis II 22, 4.

38 Procopius, De bellis II 22, 7-8, tł. własne. 
liczbę zmarłych na danym terenie, a powracającego bezlitośnie tam, gdzie na początku żniwo śmierci było niewielkie, aby wyrównać rachunek zgonów ${ }^{39}$. Prokopiusz odnotowuje, że pierwszy atak zarazy trwał w mieście przez cztery miesiące, największe nasilenie osiągnęła w miesiącu trzecim. Na początku liczba osób umierających nie była wiele większa niż zazwyczaj, później gwałtownie się wzmogła. Liczba zmarłych dziennie dochodziła do pięciu tysięcy, potem nawet do dziesięciu tysięcy i więcej ${ }^{40}$.

\section{Próby ustalenia przyczyn epidemii}

Tukidydes na samym początku swej relacji rezygnuje z dociekań w tej kwestii ${ }^{41}$, uznając to za bezcelowe i nieistotne, zwłaszcza w przypadku choroby, która nawet dla lekarzy pozostawała zagadką i nie znali żadnych skutecznych metod walki z nią ${ }^{42}$. Poza przyczynami naturalnymi, jakie próbowano ustalić z mniejszym lub z większym prawdopodobieństwem, (domniemane zatrucie wody w studniach w Pireusie), nie znajdziemy w dziele Tukidydesa innych sugestii tego typu. Zwraca on natomiast uwagę na niezwykle istotny czynnik psychologiczny, jaki mógł wzmacniać poczucie lęku i zagrożenia wśród zamkniętej w obrębie murów miejskich społeczności, a jednocześnie tłumaczyć przyczyny wystąpienia epidemii.

Zarówno Ateńczycy, zamknięci w mieście, jak i Spartanie, oblegający miasto, mieli przed oczyma obraz boga Apollona zsyłającego na wal-

39 Por. Procopius, De bellis II 22, 8: „Jeśli zaś pominęła jakiś obszar, albo nie dotykając tamtejszych mieszkańców albo czyniąc to w nieznacznym stopniu, to później powracała tam znowu, ale nie dotykała już ich sąsiadów, których wcześniej potraktowała najsurowiej, lecz z tego danego kraju nie ustępowała wcześniej, dopóki nie oddała właściwej i sprawiedliwej miary co do liczby zmarłych, która [odpowiadała liczbie] tych mieszkańców sąsiednich okolic, którzy poprzednim razem ulegli zagładzie”, tł. własne.

40 Por. Procopius, De bellis II 23, 1-2. Inni autorzy piszący o tej epidemii podają podobne liczby. Zob. Evans, Justynian i Imperium Bizantyńskie, s. 35: „Zatem kiedy ten bicz boży zawisł nad miastem, od samego początku zaczął atakować biedotę, tych, którzy leżeli na ulicach. Zdarzało się, że 5000 i 7000, a nawet 12000 albo i więcej niż 16000 z nich opuściło [ten świat] jednego tylko dnia". Autor cytuje fragmenty z tzw. Kroniki Pseudo-Dionizego z Tell-Mahre, która została napisana w języku syryjskim, ale opis plagi został skopiowany z drugiej (niezachowanej) części Historii Jana z Efezu, który podobnie jak Prokopiusz był naocznym świadkiem tej epidemii.

41 Por. Thucydides, Historiae, II 48, 3.

42 Thucydides, Historiae II 47, 4: „Lekarze bowiem nic nie mogli pomóc, gdyż na początku leczyli bez znajomości choroby [...]”, tł. Kumaniecki, s. 156. 
czących pod Troją Achajów strzały zarazy ${ }^{43}$. Apollon jako opiekun lekarzy i sztuki medycznej oraz ojciec Asklepiosa był pierwszym bóstwem wzywanym przy składaniu przysięgi lekarskiej ${ }^{44}$ znanej jako przysięga Hipokratesa, bóstwem raczej groźnym i budzącym lęk. Jako bóg władający w Delfach - najważniejszej wyroczni świata helleńskiego - miał wpływ, poprzez usta Pytii i swoich kapłanów, na najważniejsze wydarzenia polityczne nie tylko całej Hellady, lecz także krajów sąsiednich. Po wybuchu wojny peloponeskiej i pojawieniu się zarazy przypomniano sobie także o pewnej starej przepowiedni, że wraz z wojną dorycką nadejdzie zaraza ${ }^{45}$, oraz o nowszej, jaką otrzymali w Delfach Lacedemończycy przed rozpoczęciem wojny z Atenami:

Wysłali poselstwo do Delf z zapytaniem, czy korzystniej będzie wojnę prowadzić czy nie. Bóg im podobno odpowiedział, że jeśli będą prowadzić wojnę z całą energią, to odniosą zwycięstwo; oświadczył również, że sam, czy to proszony, czy nie proszony, będzie im pomaga ${ }^{46}$.

43 Agamemnon znieważył kapłana Apollona - Chryzesa, który z kolei poprosił Apollona o ukaranie butnego władcy: ,Wysłuchał go Fojbos Apollon: / Zstąpił ze szczytów Olimpu z sercem od gniewu wzburzonym, / łuk przewiesiwszy przez ramię i kołczan z dwóch stron zamknięty. / Strzały dźwięknęły na barkach rozgniewanego okrutnie, / gdy się poruszył. Do nocy był nadchodzącej podobny. / Siadł od okrętów daleko i pierwszą wypuścił strzałę. / Ozwał się dźwiękiem straszliwym srebrzysty łuk Apollona. / Najpierw skierował swe groty na rącze psy oraz muły, / potem jął ostre pociski miotać na ludzi śmiertelnych. / Stosy bez przerwy płonęły żałobne nieprzeliczone. / Dziewięć dni strzały miotane przez boga na obóz padały [...]" (Homerus, Ilias I 43-53, w: Homer, Iliada, tł. K. Jeżewska, Biblioteka Antyczna, Warszawa 1999, s. 26).

44 Hippocrates, Ius iurandum 1, w: Hippocrates, t. 1, tł. W.H.S. Jones, Cambridge - London 1923, s. 12-64. Najnowsze tłumaczenie na język polski znajduje się w: Hippokrates, Wybór pism, t. 1, tł. M. Wesoły, Biblioteka Antyczna 41, Warszawa 2008, s. 54: „Przysięgam na Apollona lekarza, na Asklepiosa, Hygieję i Panakeję [...]”.

${ }^{45}$ Por. Thucydides, Historiae II 54, 1-4. Inni mówili o głodzie, który miał pojawić się, według tej przepowiedni, wraz z wojną dorycką. Tukidydes dość sceptycznie ocenia tę interpretację ex post. Zwraca uwagę na podobieństwo wyrazów: (loimos - 'zaraza', limos - 'głód') oraz krytycznie ocenia wnioski, jakie wysuwają ludzie, przytaczając dawne przepowiednie post factum. Stwierdza, iż dopasowują oni formę tych przepowiedni do zaistniałej sytuacji i jeśli nadejdzie kiedyś kolejna wojna dorycka, a wraz z nią głód, wtedy zinterpretują je zgodnie z tym, co się wydarzy.

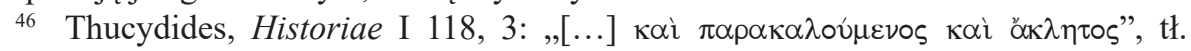
Kumaniecki, s. 95. Por. Papanikos, Thucydides and the Synchronous Pandemic, s. 84-86. Autor zwraca uwagę na dwuznaczność tej wyroczni, jakkolwiek wydaje się ona oczywista. Apollon zaznacza, że przybędzie z pomocą, jeśli Peloponezyjczycy będą prowadzili 
Otóż wydawało się, że wypadki zgadzają się z tą przepowiednią: zaraza bowiem wybuchła wnet po wkroczeniu Peloponezyjczyków ${ }^{47}$.

Zdaniem historyków było to działanie dokładnie zaplanowane w celu pozyskania zgody sprzymierzeńców na wypowiedzenie Atenom wojny ${ }^{48}$. Tukidydes spogląda $\mathrm{z}$ chłodnym dystansem na pomysł bezpośredniej ingerencji Apollona w działania wojenne, chociaż nie lekceważy destrukcyjnego efektu psychologicznego, jaki wywierało na dręczonych straszliwą chorobą mieszkańców Aten przekonanie, iż to sam Apollon wspomaga nieprzyjaciela ${ }^{49}$.

Prokopiusz, podobnie jak Tukidydes, odżegnuje się od poszukiwania konkretnych, naturalnych przyczyn śmiercionośnej choroby. Za jedyną przyczynę proponuje uznać wolę Boga: „Jednak w przypadku tego nieszczęścia nie ma możliwości, aby wyrazić w słowach lub sformułować w myślach jakąś [jego] przyczynę, chyba że odniesiemy te sprawy do Boga

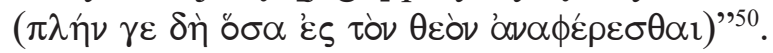

Prokopiusz wyszydza nawet śmiałków, którzy zamierzaliby podawać wyjaśnienia wszystkich spraw zsyłanych przez niebo, twierdząc, że tacy ludzie biegli są w tworzeniu dziwacznych, niezrozumiałych teorii związanych ze zjawiskami naturalnymi, ale robią to dla zyskania taniego poklasku, świadomie używając oszustwa i wiedząc, że nie mówią niczego sensownego. Komentarz ten brzmi dość ironicznie i zjadliwie, pojawia się W nim określenie: $\sigma o \phi^{\prime} \sigma \mu \alpha \tau \alpha \alpha^{\prime} \imath \tau^{\prime} \alpha \varsigma$ (,kunsztowne, wydumane pomysły co do przyczyny choroby") ${ }^{51}$ i różni się w tym miejscu od chłodnego stylu Tukidydesa, który odniósł się z całkowitą obojętnością co do ewentualnych komentarzy na temat przyczyn epidemii.

Mówiąc o woli niebios czy woli Boga jako o możliwej przyczynie choroby, Prokopiusz nigdzie nie wspomina, że epidemia ta mogłaby stanowić

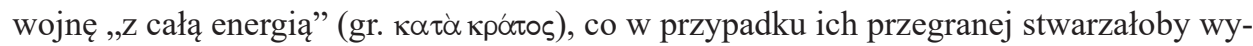
godne usprawiedliwienie braku boskiej interwencji.

47 Thucidydes, Historiae II 54, 5, tł. Kumaniecki, s. 161-162.

48 Bravo, Historia Starożytnych Greków, s. 147: „W jakiej mierze owa wyrocznia była spartańską manipulacją, a w jakiej inicjatywa wyszła od samych Delf - od pokoju trzydziestoletniego znajdujących się w obszarze spartańskich wpływów - nie wiemy”.

49 O roli wyroczni delfickiej w dziele Tukidydesa i sceptycznym do niej stosunku ateńskiego historiografa, zob. V. Liotsakis, Texts of Religious Content in Thucydides and the Implied Ancient Reader ,Rivista di Fililogia e di Instruzione Classica” 143/2 (2015) s. 278-317.

50 Procopius, De bellis II 22, 2, tł. własne.

51 Procopius, De bellis II 22, 3, tł. własne. 
zbiorową karę zesłaną na ludzi z powodu popełnianych przez nich grzechów. Działanie boskie jako czynnik sprawczy choroby pozostaje tajemnicze i niewyjaśnione, nie znajdujemy też w tym opisie żadnych sugestii, że Bóg poprzez tę chorobę miałby na celu skłonienie ludzi do poprawy życia, do nawrócenia i pokuty ${ }^{52}$.

\section{Objawy i przebieg choroby}

Przekaz Tukidydesa dotyczący objawów i przebiegu choroby jest bardzo precyzyjny, zwięzły, zawiera fachowe terminy medyczne używane w szkole Hipokratesa ${ }^{53}$ : ludzie w pełni zdrowia zapadali na nią nagle i właściwie bez przyczyny. Jeśli natomiast ktoś cierpiał na jakieś inne schorzenie, to szybko przechodziło ono w tę właśnie chorobę ${ }^{54}$. Najczęściej zaczynała się ona nagle, atakując organizm od głowy, która stawała się rozpalona, a gardło i język - przekrwione, oddech chorego był cuchnący. Pojawiała się chrypka i gwałtowny kaszel powodujący ból

52 Ani u Tukidydesa, ani u Prokopiusza nie pojawia się przy opisie epidemii topos choroby jako kary zsyłanej przez bóstwo czy Boga na ludzi. Jest to jednen z toposów wyszczególnionych w: Duncan-Jones, The Impact of the Antonine Plague, s. 112-115.

53 Wśród lekarzy, epidemiologów, historyków, filologów i innych badaczy zajmujących się relacją Tukidydesa po dzień dzisiejszy trwa dyskusja, czy użyta przez niego terminologia jest terminologią stosowaną w ówczesnej medycynie, czy jest to bardziej swobodny, literacki sposób przekazu informacji. Por. J. Kołodyński, Zagadkowa przyczyna plagi ateńskiej wyjaśniona!, „Archeologia Żywa” 4 (2006) s. 54. Większość badaczy jednak zajmujących się antyczną medycyną grecką nie podziela takiej opinii. Problem ten porusza James Longrigg, wysuwając bardzo mocne argumenty za wiarygodnością Tukidydesa w kwestiach zarówno medycznych, jak i językowych. Zob. J. Longrigg, The Great Plague of Athens, „History of Science” 18 (1980) s. 211-212. Podobną opinię wyraża też Romuald Turasiewicz, w: Tukidydes, Wojna peloponeska, tł. K. Kumaniecki, opr. R. Turasiewicz, Wrocław - Warszawa - Kraków 1991, s. LXII. Umiejętne posługiwanie się terminologią medyczną przez ateńskiego historyka nie stoi w sprzeczności z faktem, iż jego opis zarazy jest mistrzowskim od strony literackiej, dramatycznym obrazem nie tylko epidemii jako takiej, ale epidemia staje się u niego symbolem wojny wyniszczającej fizycznie i moralnie całą społeczność. Opis zarazy umieszczony został zaraz po słynnej mowie pogrzebowej Peryklesa stanowiącej panegiryk na cześć potęgi i kultury ateńskiej, co miało potęgować przerażający obraz klęski, upadku i rozkładu życia społecznego, jakie przynosi ze sobą zaraza, czyli wojna. Zob. T.E. Morgan, Plague or Poetry? Thucydides on the Epidemic of Athens, ,Transactions of the American Philological Association” 124 (1994) s. 197-209.

54 Por. Thucydides, Historiae II 49, 1. 
w piersiach. Do tego dochodziły bardzo bolesne wymioty żółcią oraz sucha czkawka. Całe ciało przybierało siny odcień i pokrywało się drobnymi pęcherzami i wrzodami, w dodatku było tak rozpalone, że chorzy nie mogli znieść dotyku nawet najcieńszej tkaniny, lecz leżeli nadzy albo nawet próbowali rzucać się na oślep do zimnej wody. Trawiło ich przy tym ogromne pragnienie, które nie ustępowało, nawet jeśli mieli pod dostatkiem wody do picia. Dochodził do tego ciągły niepokój i bezsenność, co jeszcze pogłębiało cierpienia zarówno chorych, jak i ich bliskich. Ciało jednak nie ulegało osłabieniu, ale wykazywało zdumiewającą odporność. Pomimo tego jednak wielu umierało siódmego lub dziewiątego dnia choroby z powodu wewnętrznej gorączki. Jeśli ktoś nie poddał się jeszcze wtedy chorobie, schodziła ona w dół, atakując brzuch i podbrzusze. Pojawiały się tam wrzody oraz silna biegunka. Chorzy umierali wtedy z wyczerpania i odwodnienia. Ci natomiast, którzy przetrwali najgorsze, tracili genitalia, palce u rąk i nóg, a niektórzy nawet wzrok ${ }^{55}$. Nie miało znaczenia, czy ktoś był słaby czy silny fizycznie - choroba atakowała jednych i drugich bez względu na wiek i płeć. Dobra kondycja i siła fizyczna, młody wiek nie gwarantowały nikomu wyzdrowienia. Nie zmieniała też sytuacji chorych opieka i stosowanie jakichkolwiek środków leczniczych. Jak już zostało wspomniane wcześniej, lekarze nie spotkali się wcześniej z podobną chorobą, nie mieli pojęcia, czym ją leczyć, ale usiłowali przynajmniej łagodzić objawy i uśmierzać ból. Podawano chorym różne lekarstwa, ale żadne $\mathrm{z}$ nich nie było skuteczne. W rezultacie umierali zarówno ci, których próbowano ratować, jak i ci, którym nie aplikowano żadnych medykamentów ${ }^{56}$. Pojawiały się takie sytuacje, że u chorych, którzy sprawiali już wrażenie, że pokonali chorobę, ponieważ ustąpiły symptomy fizyczne, występowały poważne zmiany w psychice: „Zdarzało się, że ludzie natychmiast po wyzdrowieniu tracili pamięć, nie zdawali sobie sprawy, kim są, i nie poznawali swoich krewnych"57.

55 Por. Thucydides, Historiae II 49, 7-8. Niektórzy uznają ten objaw (utratę kończyn) za skutek gangreny, a co za tym idzie, miałoby to potwierdzać teorię tyfusu: „Evidently as the results of gangrene, due to stoppage of circulation. This after-effect of typhus was of common occurence in the outbreak in the Balkans in 1915" (Thucydides, History of the Peloponesian War, tł. CH.F. Smith, London 1956, s. 347, przyp. 1).

56 Por. Thucydides, Historiae II 51, 2: „Jedni umierali z braku opieki, inni mimo najstaranniejszej opieki. Nie było też ponoć żadnego lekarstwa, którego zastosowanie zapewniałoby powrót do zdrowia; to bowiem, co pomagało jednym, szkodziło drugim”, tł. Kumaniecki, s. 159.

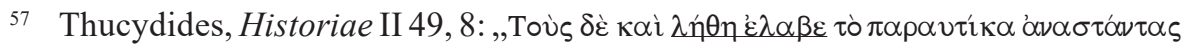

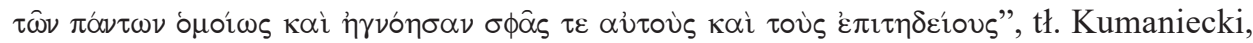


Tukidydes trafnie zauważa, że nie tylko brak odpowiednich środków leczniczych wpływał na dużą śmiertelność chorych. Niezwykle ważnym faktorem był czynnik psychologiczny: „Najgorszą zaś rzeczą w tym nieszczęściu była depresja psychiczna, występująca u każdego, kto poczuł się chory - tracił bowiem nadzieję i poddawał się chorobie, pozbawiony odporności" ${ }^{58}$. Depresja pojawiała się u tych chorych, którzy widzieli masowo umierających wokół siebie innych ludzi i przerażeni skalą epidemii zdawali sobie sprawę, że szansa na ocalenie jest niewielka. W ten sposób jeszcze bardziej osłabiali swój system odpornościowy, zamykając się w błędnym kole choroby i śmierci ${ }^{59}$.

W relacji Prokopiusza passus dotyczący objawów choroby jest bardziej rozbudowany i zawiera więcej szczegółowych informacji. W dodatku dość długi fragment Prokopiusz poświęca tajemniczym zjawiskom, które

s. 158. Również te objawy stanowią argument dla niektórych lekarzy i innych badaczy utożsamiających epidemię w Atenach z tyfusem. Zob. Gomme, A Historical Commentary on Thucydides, t. 2, s. 153. Podczas przeprowadzonych w Atenach w latach 1994-1995 prac archeologicznych w pobliżu dawnego cmentarza Kerameikos znaleziono w pojedynczej jamie dużą grupę szkieletów ułożonych w pięciu warstwach nierozdzielonych ziemią. Warstwy dolne ułożone zostały w sposób uporządkowany, warstwy górne - chaotycznie i bezładnie, tak jakby zwłoki wrzucano w pośpiechu. Niewiele też znalazło się tam ofiarnych artefaktów, co pozwala przypuszczać, iż pogrzeby tych zmarłych odbyły się niezgodnie z klasyczną tradycją, zapewne w nadzwyczajnych okolicznościach, na przykład podczas epidemii. W próbkach pobranych od tych szkieletów stwierdzono obecność dawnego DNA bakterii, które okazało się szczepem z gatunku Salmonella enterica serotyp Typhi. Potwierdzałoby to teorię o tyfusie jako chorobie, którą opisuje Tukidydes (Kołodyński, Zagadkowa przyczyna plagi ateńskiej wyjaśniona!, s. 54-56). Nie wszystkich jednak badaczy przekonuje ten dowód. Zwracają oni uwagę na niepewne datowanie szkieletów, które jest przybliżone z dopuszczalnym błędem nawet do kilkudziesięciu lat (J. Molenda, Wyspy greckie. Przewodnik historyczny. Kontrowersyjne dzieje Hellady, Warszawa 2014, s. 52-57). Objawy opisane przez Tukidydesa wydają się autorowi bliższe wirusowym gorączkom krwotocznym, takim jak wirus Ebola czy wirus Marburg.

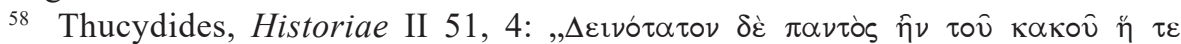

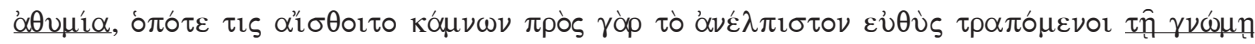

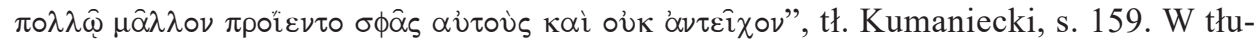
maczeniu bardziej dosł. „ilekroć ktoś poczuł się chory, natychmiast tracił nadzieję i poddając się przede wszystkim na duchu nie wytrzymywał choroby/nie opierał się chorobie".

59 Lekarze antyczni zwracali baczną uwagę na czynnik psychologiczny w leczeniu, zwłaszcza na lęk pacjenta, jaki towarzyszy każdej chorobie i jego wpływ na proces leczenia. W różnych dziełach należących do Corpus Hippocraticum pojawiają się uwagi na ten temat. Zob. Decorum XVI, t. 2, w: Hippocrates, s. 12-64. 
miały rzekomo poprzedzać atak choroby ${ }^{60}$. Nie twierdzi przy tym, że sam doświadczył podobnych wizji, raczej zebrał on relacje osób, które przeżyły epidemię i być może pragnęły udramatyzować swoje wspomnienia. Wielu ludziom, którzy zachorowali, miały tuż przed chorobą ukazać się zjawy w ludzkiej postaci, które uderzały ich w jakąś część ciała, a ci mieli w tym momencie popadać w chorobę. Uważano te widma za demony, złe duchy, dlatego uciekano przed nimi do świątyń, gdzie zanoszono różnorakie modły i składano ofiary, albo do własnych domów. Tam zamykano drzwi i nie otwierano nikomu, nawet przyjaciołom i bliskim, gdy pukali, nawoływali i usiłowali wejść do środka, ponieważ ich również uznawano za demony. Inni z kolei mieli widzenia senne, w których pojawiały się cierpiące postaci i jednocześnie sami zaczynali odczuwać podobne cierpienia lub postaci te przepowiadały im w sposób niezwykle dramatyczny, że ,zostali wpisani w liczbę tych, którzy mają umrzeć" ${ }^{61}$.

W końcu jednak Prokopiusz przyznaje, że zdecydowana większość zapadała na chorobę nagle, bez żadnego ostrzeżenia, czy to we śnie, czy na jawie ${ }^{62}$, atakowani byli przez chorobę o różnych porach dnia. Ciało nie zmieniało nagle ani kolorytu ani temperatury, ponieważ gorączka rozwijała się bardzo powoli, tak że niekiedy od rana do wieczora nic nie budziło niepokoju ani samego chorego, ani lekarza, który go badał. Na początku epidemii w ogóle nie obawiano się śmierci z powodu wystąpienia takich objawów. Dopiero gdy w pachwinach, na udach, a nawet w okolicach uszu zaczęły rozwijać się i nabrzmiewać guzy (czasami od razu, czasami po

60 Por. Gomme, A Historical Commentary on Thucydides, t. 2, s. 146. Gomme jako autor komentarza historycznego uznaje te opowieści za bezsensowne i niepotrzebne, chociaż od strony literackiej dodają swoistego kolorytu i dramatyzmu opowieści. Z kolei Alanna Nobss w artykule na temat dygresji w dziełach Prokopiusza zaznacza, iż były one z jednej strony wyrazem jego inwencji i stylu, a z drugiej odpowiadały gustowi literackiemu ówczesnej epoki, i oczekiwaniom czytelników. Zob. A. Nobss, Digressions in Procopius, w: Le Monde de Procope / The World of Procopius, red. G. Greatrex S. Janniard, Orient \& Mediterranée 28, Paris 2018, s.163-171. Prokopiusz ani nie neguje, ani nie potwierdza wiarygodności tych relacji, można też uznać te opowieści za ciekawy zapis obserwacji związanych z pewnym aspektem ludzkiej psychiki. Człowiek, który doświadczył jakiegoś poważnego nieszczęścia, katastrofy, choroby, bardzo często dodatkowo dramatyzuje swoje przeżycia, aby w ten sposób podkreślić ich wyjątkowość. W sytuacji epidemii dodatkowym czynnikiem wpływającym na tego typu ,wizje” jest też zbiorowa panika i histeria.

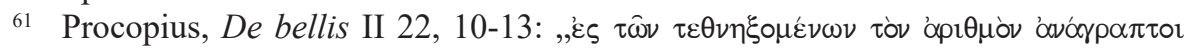

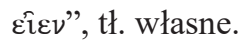

62 Por. Procopius, De bellis II 22, 14. 
kilku dniach), choroba zaczęła wzbudzać większy niepokój. Stąd też, na podstawie opisu Prokopiusza oraz innych autorów tego okresu, przyjmuje się, że epidemią, która dotknęła wtedy Konstantynopol, była dżuma dymieniczna ${ }^{63}$. Prokopiusz zaznacza, że do tego momentu objawy były mniej więcej podobne u wszystkich zaatakowanych. Później jednak pojawiły się wyraźne różnice w trakcie rozwoju choroby.

Najczęściej przebiegała ona dwutorowo: chorzy albo wpadali w głębo-

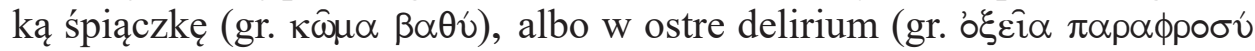

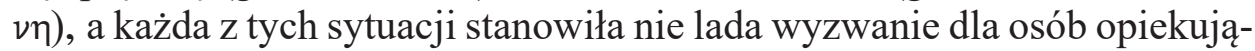
cych się chorymi. W pierwszej sytuacji „wydawało bowiem się, że ci, którzy zapadali w śpiączkę, będą spali wiecznie, zapomniawszy o wszystkim, co było im bliskie. A jeśli ktoś troszczył się o nich, to jedli coś w międzyczasie, inni natomiast, pozbawieni opieki, umierali szybko z powodu braku pożywienia" ${ }^{64}$.

Nieporównanie więcej problemów jednak sprawiali chorzy, którzy wpadali w delirium: cierpieli oni na bezsenność oraz nadpobudliwość i chorobliwą wyobraźnię - obawiali się swoich opiekunów, wpadali w popłoch i krzycząc głośno, rzucali się do panicznej ucieczki. Dlatego też osoby zajmujące się takimi chorymi były otoczone powszechnym współczuciem, ponieważ znajdowały się często w stanie skrajnego wyczerpania - były zmuszone pilnować nieustannie chorych spadających z łóżek i turlających się po ziemi, kłaść ich ponownie na miejsce, a gdy chcieli wybiec $\mathrm{z}$ domu, siłą zatrzymywać i wciągać z powrotem ${ }^{65}$. Ci zaś, którym udało się uciec, biegli przeważnie w kierunku morza, żeby się w nie rzucić, stąd też Prokopiusz wyciąga wniosek, że nie było to spowodowane pra-

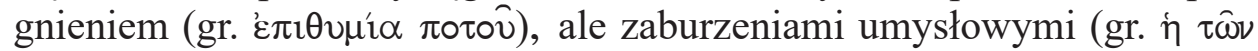

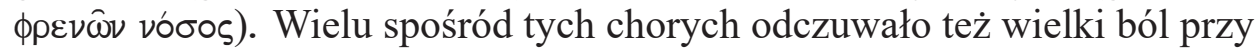
spożywaniu pokarmów, dlatego, jeśli nie mieli nikogo, kto by się nimi zajął, umierali z głodu albo owładnięci delirium, ginęli, skacząc gdzieś z wysoka $^{66}$. Prokopiusz przedstawia też trzecią grupę chorych, tych, których nie zaatakowała ani śpiączka, ani delirium, ale w ich guzach pachwinowych

63 Por. Procopius, De bellis II 22, 15-17. Zob. przyp. 14. Nie wszyscy badacze podzielają ten pogląd. Por. C. Duncan - S. Scott, Czarna śmierć. Epidemie w Europie od starożytności do czasów współczesnych, tł. A. Siennicka, Warszawa 2004. O ile w przypadku zarazy ateńskiej autorzy całkiem słusznie odrzucają przypuszczenie, że chodziło o dżumę, to jednak w przypadku plagi Justyniana pogląd ten nie wydaje się uzasadniony.

64 Procopius, De bellis II 22, 19-20, tł. własne.

65 Por. Procopius, De bellis II 22, 21-24.

66 Por. Procopius, De bellis II 22, 25-26. 
pojawiała się gangrena i umierali w straszliwych cierpieniach ${ }^{67}$. Były też osoby, u których opuchlizna pachwinowa powiększała się i zaczynała ropieć, a tym udawało się wyjść z choroby i pozostać przy życiu. Prokopiusz zamieszcza w tym punkcie swego opisu obserwacje i wnioski, jakie mógłby zamieścić uważny lekarz, dotyczące przebiegu choroby:

Ponieważ było oczywiste, że w ten sposób zaostrzony stan guza dymienicznego ulegał złagodzeniu i było to przeważnie wyraźną oznaką powrotu do zdrowia. W tych zaś przypadkach, gdy opuchlizna pozostała w poprzedniej, niezmienionej postaci, utrzymywały się też te nieszczęścia (tzn. śmierć w strasznych cierpieniach), o których wspomniałem ${ }^{68}$.

Pojawiały się też przypadki ozdrowieńców, którym nabrzmiałe guzy pachwinowe nie rozwinęły się w ropiejące wrzody, ale tym usychało udo ${ }^{69}$. Byli też tacy, którym udawało się przeżyć, ale cierpieli później na problemy z mówieniem, albo seplenili, albo wypowiadali słowa niewyraźnie i z trudem ${ }^{70}$. Oprócz guzów pachwinowych można było zaobserwować jeszcze inne objawy, podobne do tych opisanych przez Tukidydesa: ciało

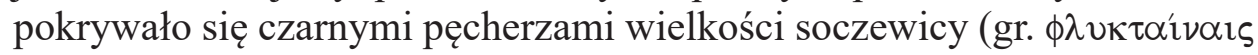

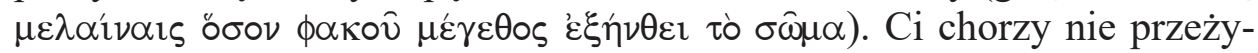
wali nawet jednego dnia (od momentu pojawienia się tych bąbli), umierali natychmiast. Innym śmiercionośnym symptomem, również wymienionym

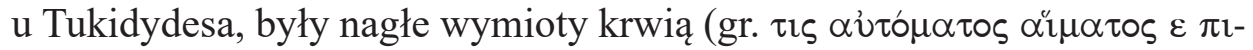

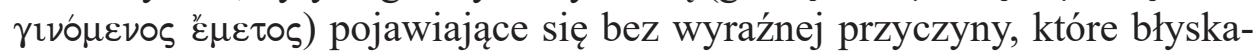
wicznie uśmiercały chorych ${ }^{71}$.

Z relacji Prokopiusza wynika, iż ówcześni lekarze nie znali tej choroby - „tak więc lekarze byli bezradni z powodu nieznajomości objawów"72. Lekarze więc, obserwując pacjentów, zwłaszcza tych, u których wystąpiły guzy, uznali, iż to właśnie w tych guzach koncentruje się cała

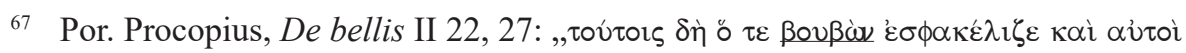

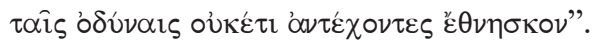

68 Procopius, De bellis II 22, 37, tł. własne.

69 Por. Procopius, De bellis II 22, 38.

70 Por. Procopius, De bellis II 22, 39.

71 Por. Procopius, De bellis II 22, 30-31.

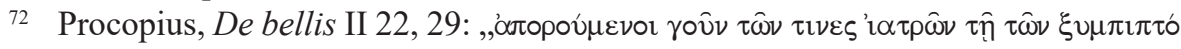

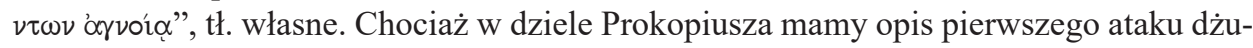
my dymienicznej na tak dużą skalę na terenach Europy, to najnowsze badania genetyczne wskazują, iż choroba ta mogła pojawiać się tam już znacznie wcześniej. Zob. M. Spyrou et al., Analysis of 3800-year-old Yersinia Pestis genomes suggests a Bronze Age origin for 
choroba i postanowili przebadać ciała zmarłych. Kiedy przecięli kilka guzów, znaleźli tam dziwny rodzaj dużego, twardego czyraka wyrośniętego wewnątrz ${ }^{73}$.

W relacji Prokopiusza znajdziemy też wzmiankę o ciężarnych kobietach, które zapadały na zarazę. Ich los był tragiczny, a śmierć - przesądzona: ,jedne bowiem umierały w czasie poronienia, a inne w czasie porodu wraz z dzieckiem, które urodziły" 74 . Co prawda doszła do niego informacja o trzech kobietach, które poród przeżyły, chociaż ich dzieci zmarły, i o jednej, która zmarła w trakcie porodu, ale jej dziecko przeżyło, choć z jego przekazu wynika, że sam nie zetknął się z takim przypadkiem ${ }^{75}$.

\section{Pomoc lekarzy oraz innych osób a zaraźliwość choroby}

Tukidydes zwraca uwagę na duży stopień zaraźliwości choroby, która spadła na Ateny, i podkreśla, że szczególnie na atak zarazy byli narażeni lekarze, którzy z powodu nieznajomości choroby nie potrafili jej leczyć i ,sami najliczniej umierali, stykając się ciągle z chorymi" 76 , oraz wszyscy ci, którzy ofiarnie i z poświęceniem opiekowali się cierpiącymi:

Straszny był również fakt, że przy pielęgnowaniu chorych jeden zarażał się od drugiego i umierali wskutek tego jak owce; to wywoływało największe spustoszenie. Jeśli bowiem unikano chorych z obawy, ginęli w osamotnieniu; wiele też domów całkiem wymarło z braku opieki. Jeśli zaś ktoś zbliżył się do chorego, giną̧ ${ }^{77}$.

Bubonic Plague, „Nature Communications” 9/2234 (2018), w: https://doi.org/10.1038/ s41467-018-04550-9 (dostęp: 30.12.2020).

73 Por. Procopius, De bellis II 22, 29. Prokopiusz nie notuje, czy miało to jakikolwiek wpływ na sposób leczenia, ale z jego opisu wynika raczej, że to badanie nie wniosło niczego istotnego ani nie zmieniło metod walki z chorobą

74 Procopius, De bellis II 22, 35, tł. własne.

75 Por. Procopius, De bellis II 22, 36.

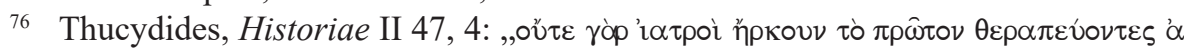

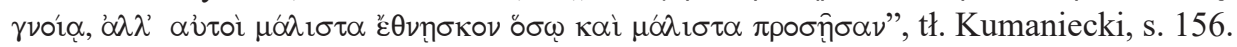

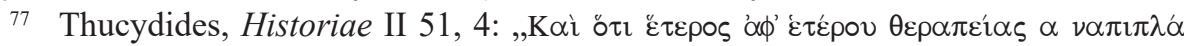

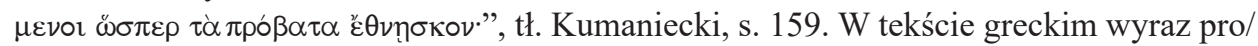
bata oznacza wszelkiego rodzaju bydło, żyjące i wypasane w stadzie, stąd thumaczenie „umierali jak owce” brzmi łagodniej niż oryginał. Tukidydes podkreśla, że ludzie padali masowo jak chore bydło w stadzie. 
Nowożytni badacze zajmujący się tekstami szkoły hipokratejskiej twierdzą, iż jest to zupełnie rewolucyjne stwierdzenie na tle ówczesnych poglądów na temat rozprzestrzeniania się chorób o charakterze epidemicznym. Choroby takie miały się rodzić i przemieszczać z jednego miejsca w drugie wraz ze szkodliwymi wyziewami - miasmata, ale jakby bez udziału człowieka ${ }^{78}$. Tukidydes jednak zjawisko zarażania przyjmuje jako oczywiste na podstawie naocznych obserwacji i własnych przeżyć. Z ogromnym przejęciem przedstawia też poświęcenie tych, którzy, nie bacząc na niebezpieczeństwo, starli się ratować przyjaciół: „Przede wszystkim ginęli najbardziej ofiarni: honor nie pozwalał im bowiem oszczędzać własnego życia i odwiedzali przyjaciół, nawet wtedy, gdy domownicy złamani nieszczęściem przestawali w końcu zwracać uwagę na jęki konających"79.

78 Takie stwierdzenie znajdziemy na przykład w: W. Naphy - A. Spicer, Czarna śmierć, tł. A. Dębska, Warszawa 2004, s. 8: „Epidemie, jak większość chorób powoduje zatrucie powietrza przez miazmaty. Obecny w nich jad zakłóca bowiem równowagę humorów cielesnych, czego następstwem staje się choroba, a czasem i śmierć. Większość tekstów medycznych odrzucała ideę, że schorzenie takie może być zakaźne. Nie zawsze jednak można z nich było wysnuwać podobne wnioski Miazmaty potrafiły bowiem zakażać nie tylko powietrze, ale i rzeczy (wełnę, ubranie), które je z niego wchłaniały. Mimo to uważano za coś oczywistego, że choroba nie może się przenosić z jednego człowieka na drugiego. W tym sensie żadna więc nie była «zaraźliwa»". Czy rzeczywiście odrzucano całkowicie możliwość zarażenia się od osób chorych? W pismach hipokratejskich znajdujemy takie oto stwierdzenia: „Pewne choroby powstają od sposobu odżywiania [diaitemata], inne od tchnienia [pneuma], którym oddychając, żyjemy. Diagnozę w jednym i drugim wypadku należy stawiać w ten sposób: gdy jednym schorzeniem objętych jest wielu ludzi w tym samym czasie, przyczynę należy przypisać temu, co okazuje się najbardziej wspólne i z czego najwięcej wszyscy korzystamy, a to jest to, czym oddychamy" (Hippokrates, O naturze człowieka IX 3, w: Hippokrates, Wybór pism, t. 1, t1. M. Wesoły, Warszawa 2008, s. 158-159). Lekarze antyczni nie mieli oczywiście pojęcia o istnieniu bakterii i wirusów czy możliwości zarażenia się drogą kropelkową, przez wydychane powietrze, ale w powyższym zdaniu przebrzmiewa intuicyjnie przeczucie, które potwierdzą dopiero nowożytne badania medyczne.

79 Thucydides, Historiae II 51, 5, tł. Kumaniecki, s. 159. Możliwa jest też inna interpretacja tekstu greckiego, ze względu na znaczenie użytego przez Tukidydesa

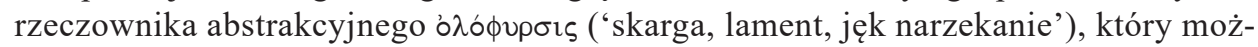
na odnieść też do opłakiwania kogoś lub czegoś, do lamentu pogrzebowego. Drugą część zdania można by zatem przetłumaczyć następująco: „gdy domownicy złamani nieszczęściem byli w końcu znużeni opłakiwaniem konających/odprawianiem lamentów nad konającymi”. Kumaniecki wybrał pierwszą z tych możliwości, jednak filolo-

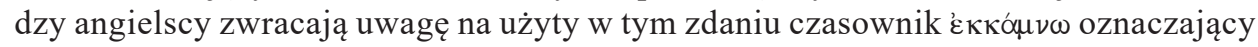
'znużyć się, zmęczyć się czymś', który odnosi się przede wszystkim do sytuacji, gdy podmiot czynności jest zmęczony tym, co sam osobiście wykonuje. Taki też sens 
Tukidydes wykazuje w tym momencie wyjątkową delikatność: chwaląc poświęcenie osób spoza rodziny, nie potępia tu tych, którzy zaprzestali zajmowania się swymi najbliższymi, podkreślając, że czynili tak ,pokonani

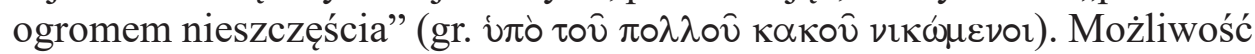
zarażania przez chorych natomiast była, jak się wydaje, tak oczywista, że tylko ci, którym udało się przeżyć chorobę, mogli bez obawy zajmować się cierpiącymi i umierającymi, co też czynili, okazując im przy tym wiele współczucia, również z tej racji, iż sami doświadczyli wszystkich bolesnych stron tej choroby ${ }^{80}$. Tukidydes podkreśla, że choroba nie atakowała ponownie tych samych osób, a przynajmniej nie ze skutkiem śmiertelnym. Wszyscy uważali ozdrowieńców za szczęśliwców, a i oni sami odczuwali z tego powodu niezwykłą radość oraz, co Tukidydes stwierdza z niejaką ironią, żywili nieuzasadnioną nadzieję, że i w przyszłości nie dadzą się pokonać żadnej innej chorobie ${ }^{81}$.

Pomimo podejmowanych prób ratowania chorych, skutków takich działań nigdy nie można było przewidzieć: „Jedni umierali z braku opieki, inni pomimo najstaranniejszej opieki. Nie było ponoć żadnego lekarstwa, którego zastosowanie zapewniałoby powrót do zdrowia; to bowiem, co pomagało jednym, szkodziło drugim" 82 .

Nie miała też znaczenia kondycja fizyczna chorego: czy ktoś był silniejszy, czy słabszy. Tukidydes w ogóle nie wspomina o takich cechach, jak wiek, czy płeć. Stwierdza po prostu, że „wszystkich kosiła ta zaraza na równi, nawet tych, których leczono wszelkimi środkami"83. Dodatkową cenną informacją, jaką przekazuje nam Tukidydes w związku z zaraźliwością tej choroby, jest wzmianka, że zarażali się nią nie tylko ludzie, ale też i zwierzęta. Odnotowuje on nietypowe w takich okolicznościach zjawisko: ptaki żerujące na padlinie i psy unikały zjadania zmarłych. Albo w ogóle nie zbliżały się do niepochowanych ciał, albo ginęły po spożyciu kilku kęsów. Dlatego zauważono wkrótce zanik tego rodzaju ptactwa, psy nato-

znajdujemy w tłumaczeniu angielskim: „For these made it a point of honour to visit their friends without sparing themselves at the time when the very relatives of the dying, overhelmed by the magnitude of the calamity, were growing weary of making their lamentations" (Thucidydes, History of the Peloponesian War, tł. Ch.F. Smith, London 1956, s. 351).

${ }^{80}$ Por. Thucydides, Historiae II 51,6.

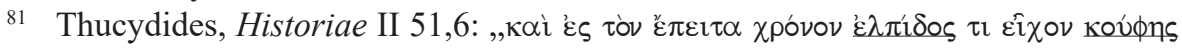

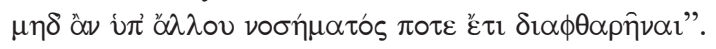

82 Thucydides, Historiae II 51, 2, tł. Kumaniecki, s. 159.

83 Thucydides, Historiae II 51, 3, tt. Kumaniecki, s. 159. 
miast, z racji towarzyszenia ludziom w życiu codziennym, padały licznie, tak jak ludzie ${ }^{84}$.

Krańcowo odmiennie o możliwości zarażenia się chorobą wypowiada się Prokopiusz, który podkreśla, iż ani lekarze, ani inne osoby opiekujące się chorymi lub zajmujące się grzebaniem zmarłych nie zarażały się poprzez kontakt dotykowy, chociaż budziło to zdziwienie, gdyż ludzie powszechnie oczekiwali takich właśnie skutków ${ }^{85}$. Prokopiusz nie wspomina też w swej relacji o zwierzętach mieszkających z ludźmi ani o innych dzikich ptakach czy zwierzętach żerujących na padlinie.

W swej dalszej relacji Prokopiusz podąża śladem Tukidydesa, przedstawiając bezradność i zagubienie lekarzy wobec tej strasznej epidemii. Zaznacza, że nawet najbardziej doświadczeni spośród nich nie potrafili przewidzieć, kto z chorych wyzdrowieje, a kto umrze. Wiele osób bowiem, co do których prognozowali zgon, ,wbrew oczekiwaniu wychodziło nietkniętych z tej opresji, a wielu takich, co do których utrzymywali, że przeżyją, miało zginąć niemal od razu"86.

Skoro nieznana była sama choroba, ani też nie istniała żadna logicznie

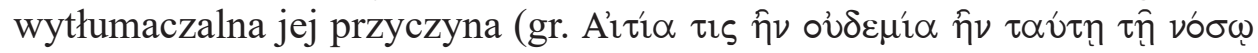

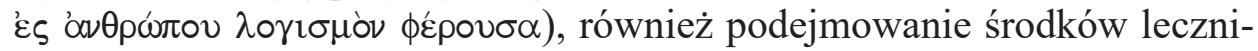

84 Por. Thucydides, Historiae II 50, 2.

85 Por. Procopius, De bellis II 22, 23. Obserwacja ta wynika z faktu, że nie znano wtedy takich pojęć, jak „okres inkubacji” czy „okres utajony choroby”, przyjmując moment pojawienia się wyraźnych objawów za moment, w którym choroba miała się zaczynać i ewentualnie stawać się zaraźliwą. Okres inkubacji - czas od zarażenia osoby do wystąpienia pierwszych symptomów. Podczas tej fazy bakterie namnażają się w zaatakowanym organizmie bez pojawiania się zewnętrznych symptomów choroby. W okresie inkubacji wyróżniamy dwie fazy: okres utajony - od momentu zarażenia do wystąpienia pierwszych objawów, oraz okres zakaźny, który może zacząć się wcześniej nim pojawią się oznaki zakażenia. Wtedy osoba zarażona zaraża innych przed wystąpieniem objawów, nieświadomie przenosząc chorobę dalej innym nosicielom. Po wystąpieniu objawów chory może nadal zarażać, ale niekoniecznie. Zwykle w tym okresie zakaźność ulega zmniejszeniu. Zob. Duncan - Scott, Czarna śmierć, s. 125. Dżuma dymieniczna jest zaraźliwa przed pojawieniem się guzów czy innych objawów choroby, gdyż jest przenoszona przez pchły, które kłując swe ofiary, wprowadzają do krwi bakterię Yersinia pestis. Po pojawieniu się guzów jej zaraźliwość znacznie się zmniejsza (chyba że mamy do czynienia z dżumą posocznicową lub płucną), nie dziwi więc powyższa obserwacja Prokopiusza. Gomme zauważa tę informację w relacji Prokopiusza, ale właśnie $\mathrm{z}$ tego powodu zarzuca mu brak wiarygodności w tym punkcie. Jak widać, nie do końca słusznie. Zob. Gomme, A Historical Commentary on Thucydides, t. 2, s. 146.

86 Procopius, De bellis II 22, 32, tł.własne. 
czych odbywało się jakby na oślep, ponieważ nikt nie był pewien, czy odniosą jakikolwiek pozytywny skutek ${ }^{87}$ :

we wszystkich bowiem przypadkach rezultat [działań] okazywał się nieprze-

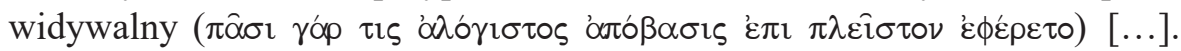
Wielu umierało z powodu braku opieki, wielu zaś innych, wbrew logice, ocalało. A metody leczenia dawały różne rezultaty w różnych przypadkach.

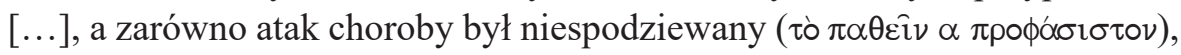

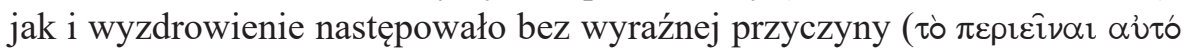
$\mu \alpha$ Tov $)^{88}$.

\section{Pogrzeby i sposoby postępowania z ciałami zmarłych}

Ponieważ obydwie epidemie szalały z niesamowitą siłą, ludzie w obliczu ogromu nieszczęścia musieli stawić czoło nie tylko cierpieniom i opiece nad chorymi, ale wkrótce pojawił się problem związany z pochówkiem zmarłych, których liczba wzrastała gwałtownie z każdym dniem. W Atenach w V wieku przed Chrystusem stosowano w normalnych okolicznościach bardzo długie i skomplikowane zwyczaje pogrzebowe: zwłoki wkładano do glinianej bądź cedrowej trumny i grzebano. Niekiedy spalano ciało na stosie, a pozostałe kości i proch zbierano do urny i grzebano. Uroczystości pogrzebowe trwały nawet kilka dni i bywały bardzo kosztowne. Oczywiście podczas epidemii nie tylko ograniczono te wszystkie obrzędy do niezbędnego minimum, ale w ogóle zarzucono wszystkie te przyjęte zwyczaje, co stanowiło złamanie zasad religijnych i oznakę najwyższej bezbożności. Tukidydes pisze z przerażeniem, że niepogrzebane trupy leżały stosami na ulicach i w świątyniach albo grzebano je, gdzie popadło. W niektórych rodzinach zmarło tak wiele osób, że pozostali przy życiu nie posiadali już środków, aby wznieść stos pogrzebowy:

Wielu z powodu licznych przypadków śmierci w rodzinie nie miało środków do palenia zmarłych i wpadło po prostu w bezwstyd; kiedy bowiem kto inny zbu-

87 Por. Procopius, De bellis II 22, 33.

88 Procopius, De bellis II 22, 33-34, tł. własne. Zarówno Tukidydes, jak i Prokopiusz nie wymieniają konkretnych metod leczenia, jakie podejmowali w przypadku zarazy lekarze, mówiąc o nich tylko w sposób ogólny. Jedynie wspomnienie o jednym z nich (kąpielach) pojawia się u Prokopiusza. 
dował stos, uprzedzali go i położywszy na nim swego zmarłego, podpalali; inni zaś, kiedy cudzy stos się palił, dorzucali zwłoki swego bliskiego i odchodzili"

O wiele dhuższy passus dotyczący grzebania zmarłych znajdujemy u Prokopiusza. Na początku również starano się palić zwłoki i każda rodzina troszczyła się o to indywidualnie, ale gdy ilość zmarłych rosła każdego dnia, ludzie zaczęli zachowywać się tak jak w czasach Tukidydesa: podrzucali cichaczem własnego zmarłego na obce stosy pogrzebowe albo umieszczali go tam wręcz siłą ${ }^{90}$. Wiele domów się wyludniło albo przeżywali tylko niewolnicy pozbawieni swych panów. Tam, gdzie wymarli wszyscy, tam wielu, nawet zamożnych mieszkańców miasta, przez wiele dni pozostawało niepogrzebanych. W rezultacie w mieście zapanował kompletny

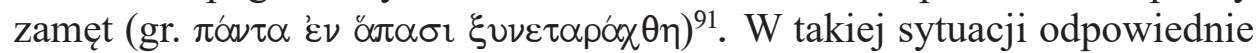
środki w kwestii organizacji uprzątania i grzebania zwłok przedsięwziął cesarz. Wyznaczył on jednego ze swych zaufanych podwładnych, Teodora, który wcześniej pełnił na dworze funkcję referendariusza, przydzielił mu żołnierzy do pomocy oraz pewną sumę pieniędzy, aby zorganizował grzebanie zmarłych, którymi nikt się nie zajął ${ }^{92}$.

Najpierw zapełniono zwłokami istniejące już groby, następnie rozkopywano wszystkie po kolei tereny wokół miasta i tam przynoszono oraz składano zmarłych. Było ich tak wielu, że osoby pracujące przy kopaniu nie mogły poradzić sobie z ogromem pracy. Wtedy przeznaczono twierdzę w Sykaj ${ }^{33}$ na jeden wielki zbiorowy grobowiec. Rozebrano dachy na wieżach tej twierdzy i tam wrzucano zwłoki kompletnie bezładnie. Kiedy wieże te się napełniły, przykryto je dachami ponownie. Niestety wkrótce potem zaczęły się wydobywać stamtąd tak cuchnące wyziewy, że docierały do mieszkańców Konstantynopola (zwłaszcza gdy wiał z tamtej strony silniejszy wiatr) i wprawiały ich w wielkie przygnębienie oraz smutek ${ }^{94}$. Zarzucono i zlekceważono oczywiście wszystkie zwyczajowe obrzędy pogrzebowe:

Zmarli bowiem byli przenoszeni nie w zwyczajowej procesji ani wśród żałobnych śpiewów, jak to zwykle [wcześniej] miało miejsce, ale wystarczało

89 Thucydides, Historiae II 52,4, tł. Kumaniecki, s. 160. Palenie zwłok nie należało do metod walki z epidemią, ale do opisanych wyżej obrzędów pogrzebowych.

90 Por. Procopius, De bellis II 23, 3.

91 Por. Procopius, De bellis II 23, 3-5.

92 Por. Procopius, De bellis II 23, 6-8.

93 Dzisiejsza Galata położona po północnej stronie zatoki Złoty Róg.

94 Por. Procopius, De bellis II 23, 9-11. 
przenieść zmarłego na ramionach i po dotarciu do terenów nadmorskich miasta, zrzucić go tam, gdzie składano ich bezładnie na kupę w łodziach, skąd mieli być przewożeni w pierwsze lepsze miejsce ${ }^{95}$.

\section{Traktowanie zasad religijnych i prawnych}

Zarzucenie zwyczajowych, wynikających ze względów religijnych obrzędów pogrzebowych wynikało oczywiście z ogromu klęski, jak spadła na mieszkańców obydwu miast. Z jednej strony epidemia powodująca w krótkim czasie tak znaczną śmiertelność przerosła zarówno poziom ówczesnej medycyny, jak i możliwości organizacyjne ówczesnych Ateńczyków oraz Bizantyńczyków, z drugiej zaś strony wywołała ogromny szok psychiczny i zachwiała wiarą w sens zwracania się z modlitwami ku bogom, czy później jedynemu Bogu, skoro nieszczęście nie mijało, a liczba ofiar wciąż rosła.

Tukidydes ocenia zaistniałą sytuację w sposób bardzo realistyczny, a nawet chłodny, chociaż nie pozbawiony goryczy i pesymizmu. Obserwując daremność wysiłków lekarzy oraz wszelkich innych prób niesienia pomocy cierpiącym, zaznacza, że „w ogóle żadna ludzka sztuka nic nie pomagała; również modlitwy w świętych miejscach, rady zasięgane u wyroczni i inne tego rodzaju sposoby zawodziły; w końcu poddano się złu z rezygnacją"96.

Początkowa bierna rezygnacja ustąpiła miejsca innemu rodzajowi zachowań. Gdy ludzie zwątpili w skuteczność wsparcia ze strony bogów, uznali, że przestrzeganie zasad religijnych, nie tylko w kwestii grzebania zmarłych, nie ma żadnego istotnego znaczenia: „Ani obawa przed bogami, ani żadne prawa ludzkie nie krępowały nikogo Jeśli idzie o bogów, ludzie uważali że pobożność tak samo nie ma żadnego znaczenia, jak i obojętność religijna; widzieli bowiem, że wszyscy na równi giną" ${ }^{97}$. Doprowadziło to do szerzenia się w mieście wszelkiego rodzaju bezprawia. Dopuszczano się jawnie tych uczynków, które wcześniej uchodziły za haniebne i pozostawały w ukryciu. Ludzie wyzbyli się hamulców moralnych i poczucia wstydu. Postawieni w obliczu nagłej i nieoczekiwanej zmienności losów zajęli się wyłącznie pogonią za przyjemnościami:

\footnotetext{
95 Procopius, De bellis II 23, 12, tł. własne.

96 Thucydides, Historiae II 47, 4, tł. Kumaniecki, s. 156.

97 Thucydides, Historiae II 53, 3, tt. Kumaniecki, s. 161.
} 
Każdy chciał prędko i przyjemnie użyć życia, uważając zarówno życie jak

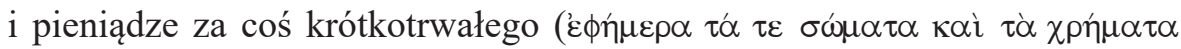

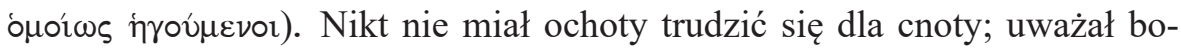
wiem, że nie wiadomo, czy nie umrze wcześniej, nim ją osiągnie; uchodziło za piękne i pożyteczne to, co było przyjemne i służyło rozkoszy ${ }^{98}$.

Widziano bogaczy, którzy codziennie umierali, a ich majątki przechodziły w całkowicie obce ręce. Najprawdopodobniej w ogóle zaprzestano rozstrzygania spraw dotyczących dziedziczenia nieruchomości i pieniędzy ani też nie nakładano żadnych kar za bezprawne zajęcie cudzego mienia, które przechodziło z rąk do rąk na zasadzie przypadku. Skoro zarówno życie ludzkie, jak i dobra materialne okazywały się tak „efemeryczne”, ludzie dochodzili do wniosku, że tym bardziej nie ma sensu dążenie do osiągnięcia rzeczy wyższych, dobra i cnoty, gdyż nie mogli być pewni, czy wcześniej nie spotka ich śmierć. W poczuciu bezkarności dopuszczano się wszelkiego rodzaju przestępstw. Obawa przed karami wymierzanymi przez sąd nie odgrywała już żadnej roli - nikt nie oczekiwał, że jakikolwiek wyrok zapadnie jeszcze za jego życia. O wiele cięższym wyrokiem wiszącym nad wszystkimi była czyhająca na każdym kroku śmierć, która stała się przez to usprawiedliwieniem korzystania za wszelką cenę z tych przyjemności życia, jakie ludziom wówczas pozostały, i jednocześnie karą za popełnione występki ${ }^{99}$.

Chociaż Tukidydes nie ocenia wszystkich mieszkańców Aten aż tak surowo, podkreślając ofiarność lekarzy, czy innych osób, które przychodziły chorym z pomocą, to jednak w jego opisie uwidacznia się raczej pesymistyczny pogląd na naturę człowieka: w sytuacji, gdy nic nie zagraża życiu ani jednostki, ani państwa, czy to wojna, czy choroba, czy inna klęska, ludzie przestrzegają zasad religijnych i prawnych, w momentach zagrożenia natomiast, w obliczu ogólnej zagłady wyrzekają się wszelkich hamulców moralnych, mają na uwadze jedynie własne przetrwanie bądź dążą na oślep do zaspokojenia najbardziej prymitywnych instynktów ${ }^{100}$.

Również wiele ciekawych obserwacji natury socjologicznej i psychologicznej dotyczących człowieka postawionego w sytuacji ekstremalnej

98 Thucydides, Historiae II 53, 2-3, tł. Kumaniecki, s. 160-161.

99 Thucydides, Historiae II 53, 2-3, tł. Kumaniecki, s. 160-161. Zob. też: C. Orwin, Stasis and Plague: Thucydides on the Dissolution of Society, „The Journal of Politics" 50/4 (1988) s. 831-847; D.A. Nielsen, Pericles and the Plague: Civil Religion, Anomie, and Injustice in Thucydides, „Sociology of Religion” 57/4 (1996) s. 397-407.

100 Zob. R. Turasiewicz, Historiografia: Herodot, Tukidydes, Ksenofont, w: Literatura Grecji starożytnej, t. 2, red. H. Podbielski, Lublin 2005, s. 31. 
znajdziemy w relacji Prokopiusza, chociaż nie są one aż tak jednoznacznie pesymistyczne. Bardzo chwalebną postawą wykazali się ci obywatele, którzy, jakkolwiek należeli do wrogich sobie, zwalczających się fakcji politycznych, zaniechali tych waśni i ,porzuciwszy wzajemną wrogość, troszczyli się wspólnie o godny pochówek osób zmarłych i sami przenosili oraz grzebali zwłoki tych, którzy nie byli ich krewnymi" ${ }^{101}$. W dodatku wiele osób diametralnie odmieniło swe życie, ale zmiana ta przebiegała jakby odwrotnie, przynajmniej na początku, niż ta opisywana przez Tukidydesa: „A ci, którzy wcześniej czerpali radość z oddawania się sprawom szpetnym i niegodziwym, odrzuciwszy od siebie niezgodne z prawem postępowanie, W życiu codziennym zaczęli sumiennie praktykować pobożność [...]”102.

Jednak i Prokopiusz w rezultacie okazuje się w swej ocenie pesymistą, czy może raczej realistą, nie bez goryczy i pewnej dozy złośliwości wyjaśniając przyczyny takiego postępowania. Wyżej wymienieni postępowa-

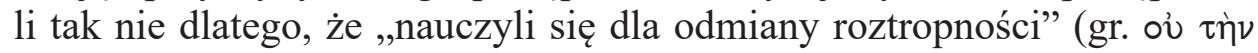
$\sigma \omega \phi \rho \circ \sigma u ́ v \eta v \mu \varepsilon \tau \alpha \mu \alpha \theta \delta$ v $\tau \varepsilon \varsigma$ ) lub ,nagle stali się miłośnikami cnoty” (gr. ou

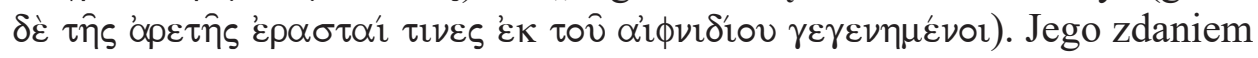
nie można tak szybko wyzbyć się złych nawyków, które zakorzeniły się głęboko w człowieku (chyba że pod wpływem boskiego natchnienia), ale takie postępowanie uwarunkowane jest strachem przed śmiercią (i ewentualną karą, która może nadejść po śmierci): „Wtedy, że się tak wyrażę, wszyscy byli z jednej strony przerażeni tym, co się działo, a z drugiej sądzili, że zaraz umrą, [a więc] pod wpływem bezwzględnego przymusu, jak to zwykle bywa, zaczęli się dla odmiany w samą porę uczyć zacności" "103. Ci sami ludzie, gdy powrócili do zdrowia i stwierdzili, że są już bezpieczni, ponieważ choroba przeniosła się na inne osoby, szybko zapomnieli o cnocie i pobożności: „Ponownie zaszła w nich nagła zmiana na gorsze i jeszcze bardziej niż wcześniej popisywali się nieprawością swych codziennych obyczajów, prześcigając samych siebie szczególnie w nikczemności oraz w innym bezprawiu"104. Prokopiusz dorzuca też ze szczególnym rozgoryczeniem, że ,choroba ta, czy to zrządzeniem losu, czy też z premedytacją, wybrała sobie precyzyjnie najbardziej nikczemnych i darowała im życie"'105.

101 Procopius, De bellis II 23,13, tł. własne.

102 Procopius, De bellis II 23,14, tł. własne.

103 Procopius, De bellis II 23,15, tł. własne.

104 Procopius, De bellis II 23,16, tł. własne.

105 Procopius, De bellis II 23, 16: „ฑ

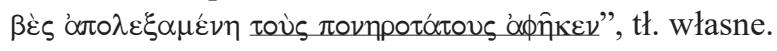


Ocena natury ludzkiej w relacji zarówno Tukidydesa, jak i Prokopiusza wydaje się mocno przesycona goryczą i pesymizmem, zwłaszcza twierdzenia, iż w sytuacji skrajnego niebezpieczeństwa giną najlepsi, którzy poświęcają swe życie dla innych, a przy życiu pozostają jednostki bezwzględne i nikczemne. Zaznacza się jednak też w ich opisie wiele współczucia dla ludzi złamanych nieszczęściem, kompletnie bezradnych wobec codziennych cierpień i zagrożonych w każdej chwili śmiercią, oraz podziw i uznanie dla tych, którzy z oddaniem pomagali bliskim, rodzinie, przyjaciołom, a nawet osobom obcym, wyrzekając się troski o własne życie i dobro, a także umieli wznieść się ponad wcześniejsze animozje polityczne, które w obliczu ogólnego zagrożenia straciły całkowicie swe znaczenie.

\section{Wpływ epidemii na życie społeczne i gospodarcze}

Epidemia powracała jeszcze do Aten przez cztery kolejne lata, do 426 roku przed Chrystusem. Najpoważniejszym jej skutkiem były wysokie straty wśród ludności, nie tylko tej zamkniętej w obrębie miasta, ale również wśród żołnierzy. Gdy spod Potidai powróciła do Aten armia Hagnona, która musiała odstąpić od oblężenia, Peloponezyjczycy, w obawie przed zakażeniem, wycofali się z Attyki. Pomimo tego Ateńczycy wysłali do Sparty poselstwo w sprawie zawarcia pokoju. O powadze sytuacji i przerażeniu Ateńczyków świadczy najdobitniej fakt, iż decyzja o zawarciu pokoju zapadła na Zgromadzeniu Ludowym wbrew woli Peryklesa. Dodatkowo decyzja Peryklesa o przeniesieniu ludności Attyki w obręb Długich Murów na czas działań wojennych, która na początku wydawała się słuszna, chroniła ją bowiem przed bezpośrednim niszczycielskim działaniem wroga, po wybuchu epidemii budziła spore wątpliwości i podkopywała autorytet Peryklesa jako przywódcy ${ }^{106}$.

W 429 roku przed Chrystusem padł ofiarą epidemii sam Perykles, co niewątpliwie miało znaczący wpływ na dalsze losy wojny. Jako polityk rozsądny i umiarkowany trzymał się on raczej defensywnej strategii prowadzenia wojny, nie chcąc narażać Aten na niepotrzebne straty. Po jego śmierci władza przeszła w ręce polityków dążących do bezwzględnej ekspansji Aten oraz realizujących przy tej okazji swe własne, prywatne interesy ${ }^{107}$. W rezultacie wojna peloponeska doprowadziła nie tylko do klęski

106 Por. Bravo, Historia Starożytnych Greków, s. 168-169.

107 Por. Thucydides, Historiae II 65, 5-10: „Jak długo bowiem [Perykles] w czasach pokojowych stał na czele państwa, kierował nim umiejętnie, ustrzegł je od niebezpie- 
i wyniszczenia samych Ateńczyków, ale również i Sparty oraz sprzymierzeńców walczących po obydwu stronach. Epidemia wygasła po 426 roku przed Chrystusem i chociaż wyhamowała działania wojenne po obu stronach, nie powstrzymała Aten i Sparty od dalszego prowadzenia wojny, która trwała z przerwami niemal trzydzieści lat ${ }^{108}$.

W Konstantynopolu życie mieszkańców w czasie epidemii ograniczało się niemal całkowicie do obrębu prywatnych domostw. Ludzie zrezygnowali całkowicie z zajmowania się polityką i sprawami publicznymi. Nawet ci, którzy oparli się chorobie, nie pojawiali się na zewnątrz - albo opiekowali się chorymi domownikami, albo, pogrążeni w żałobie, opłakiwali zmarłych. Wychodzili czasami z domu jedynie po to, aby wynieść z niego zwłoki bliskich. Długofalowym skutkiem epidemii był zanik wszelkiego rodzaju rzemiosła i handlu, a następnie skrajny głód. Chleb stał się rzeczą o najwyższej wartości, a przy tym najtrudniejszą do zdobycia. Wiele osób, nawet tych, które przeżyły chorobę, zmarło później wskutek wyczerpania i braku najpotrzebniejszych środków do życia ${ }^{109}$. Zachorował nawet sam cesarz Justynian, któremu jednak udało się uniknąć śmierci. Dżuma zabrała w 542 roku około połowę mieszkańców miasta (według innych szacunków około 40\%). Powracała jeszcze kilkakrotnie, na przykład w 558 roku, i praktycznie przetoczyła się przez całe cesarstwo. Uniemożliwiła żniwa i winobranie, spowodowała niedostatek rąk do pracy w rolnictwie, co w rezultacie przyniosło głód, gwałtowną podwyżkę cen żywności i wynagrodzeń za pracę ${ }^{110}$. „Handel praktycznie zanikł, bo mieszkańcy miast uciekli

czeństw i doprowadził do największej potęgi, kiedy zaś przyszła wojna, trafnie ocenił jej znaczenie. Żył w czasie wojny jeszcze dwa lata i sześć miesięcy; po śmierci okazało się tym jaśniej, jak dobrze przewidywał przebieg wojny. Powiedział bowiem, że Ateńczycy odniosą zwycięstwo, jeśli zachowają spokój, jeśli szczególną troską otoczą flotę, nie będą dążyć do nowych zdobyczy terytorialnych w czasie tej wojny i nie będą miasta narażać na niebezpieczeństwo. Ateńczycy postąpili wprost przeciwnie - podejmowali szkodliwe dla siebie i sprzymierzeńców akcje, niewiele z tą wojną, jak się zdaje, mające wspólnego, popychani ambicją jednostek i ich chęcią zysku.[...] Wśród późniejszych przywódców nie było ludzi wybitnych, lecz każdy starał się być pierwszym; dlatego zaczęli schlebiać ludowi, a niekiedy poświęcali dla tego celu interesy państwa”, tł. Kumaniecki, s. 125.

108 Zob. J. Martínez, Political Consequences of the Plague of Athens, „Graeco-Latina Brunesia" 22/1 (2017) s. 135-146.

109 Por. Procopius, De bellis II 23, 18-21.

110 Por. Świat Bizancjum, t. 1, s. 42, 233. Inni badacze szacują straty w ludziach na około 20-30\% populacji całego cesarstwa. Evans z kolei podaje, że w samym Konstantynopolu dżuma mogła zabić do 60\% ludności. Zob. Evans, Justynian i Imperium Bizantyńskie, s. 30 . 
na wieś albo wymarli. W miarę szerzenia się zarazy pustoszały wsie i majątki ziemskie. Gospodarka podupadła z powodu wyludnienia" "111. W dodatku większa śmiertelność panowała wśród ludzi młodych, co w przypadku powracania choroby średnio co kilkanaście lat przyniosło tragiczne skutki demograficzne ${ }^{112}$. Prokopiusz w swej Historii sekretnej, krytykując poczynania Justyniana, podkreśla, że przy potrójnych czy nawet poczwórnych podwyżkach cen żywności ludność przymierała głodem, a rolnicy pozostali przy życiu nie tylko nie uzyskali żadnych ulg podatkowych, lecz musieli płacić podatki i ze swoich własnych dóbr oraz z tytułu ziem należących do ich zmarłych sąsiadów, które to ziemie i tak leżały odłogiem z powodu braku rąk do pracy ${ }^{113}$.

Cyril Mango podkreśla też katastrofalny wpływ nawracającej epidemii na życie miejskie nie tylko w Bizancjum, ale w innych ośrodkach miejskich nad Morzem Śródziemnym i w Azji Mniejszej. Ośrodki te osłabione przez straty wywołane epidemią ulegały bądź atakom zewnętrznym, bądź rozpadały się wskutek wewnętrznych konfliktów. Zapaść ekonomiczna nie pozwalał na ich odbudowę, w rezultacie niektóre nie podniosły się już nigdy z upadku, a inne zaczęły odżywać dopiero w IX czy X wieku ${ }^{114}$.

Epidemia nawiedzająca Bizancjum wygasła dopiero w połowie VIII wieku. W roku 600 ludność w cesarstwie wynosiła tylko 60\% liczby z 500 roku. Bardzo osłabiło to armię, która zmuszona do walki na wielu frontach, od Hiszpanii, przez Italię, po Afrykę Północną, zmniejszyła znacznie swą liczebność, co zmusiło władców bizantyńskich do wycofania wojsk z zachodniej części świata śródziemnomorskiego. Cesarstwo bizantyńskie, atakowane $\mathrm{z}$ wielu stron, nie było w stanie skutecznie się bronić, ale „również Persja uległa ogromnemu osłabieniu. [...] Zarówno Bizancjum, jak i Persja były konglomeratem scentralizowanych wspólnot miejskich, żyjących z handlu. Szkody wyrządzone przez zarazę ułatwiły koczowniczym

111 Naphy - Spicer, Czarna śmierć, s. 10.

112 Zob. C. Mango, Historia Bizancjum, tł. M. Dąbrowska, Gdańsk 1997, s. 69; S. Mitchell, A History of the Later Roman Empire, AD 284-641, Chichester 2015, s. 410-413 oraz 479-491; L.K. Little, Life and Afterlife of the First Plague Pandemic, w: Plague and the End of Antiquity. The Pandemic of 541-750, red. L.K. Little, Cambridge 2016, s. 3-32.

113 Zob. Procopius, Historia arcana VIII 23.

114 Zob. Mango, Historia Bizancjum, s. 70-74. Zob. też: D. Stathakopoulos, Crime and Punishment: The Plague in the Byzantine Empire, 541-749, w: Plague and the End of Antiquity. The Pandemic of 541-750, red. L.K. Little, Cambridge 2016, s. 99118; D. Stathakopoulos, The Justinian Plague revisited, „Byzantine and Modern Greek Studies" 24 (2000) s. 256-276. 
plemionom arabskim, świeżo nawróconym na islam, zagarnięcie rozległych terenów obydwu imperiów"115.

\section{Podsumowanie}

Relacja Tukidydesa, bezpośredniego uczestnika opisywanych wydarzeń, jako pierwsza tego typu relacja w dziejach literatury europejskiej dotycząca choroby epidemicznej, jej objawów oraz wpływu na człowieka $\mathrm{w}$ jego wymiarze indywidualnym i społecznym pozostaje pomimo osobistego zaangażowania autora relacją obiektywną, pozbawioną zbędnych emocji ${ }^{116}$, a dzięki dokładnemu i metodycznemu przedstawieniu najistot-

115 Zniszczenia, jakie przyniosła zaraza w całym basenie Morza Śródziemnego i jej skutki przede wszystkim w sferze ekonomicznej, trwające przez kilka wieków, podsumowuje trafnie jeden z cytowanych już autorów: „Do tej pory jeszcze można się w Syrii natknąć na ruiny opustoszałych bizantyńskich wsi, willi, klasztorów i pomniejszych miast. Niegdyś otaczały je pola uprawne, dzisiaj są to skąpo zaludnione pastwiska. Przed nadejściem pierwszej pandemii na pustyni Negew istniały liczne wspólnoty zakonne, utrzymujące się dzięki starannie uprawianym i nawadnianym okolicznym gruntom. Kiedy klasztory porzucono, pola ponownie zamieniły się w pustynię i pozostawały w tym stanie aż do schyłku XIX wieku. Gospodarstwa drobnych właścicieli ziemskich niegdyś pokrywały Afrykę Północną, zwłaszcza Libię. Dżuma zniszczyła je, rujnując cały system irygacyjny, po czym ziemie te również obróciły się w pustynię. Nie tylko główne szlaki handlowe całego Cesarstwa załamały się z powodu wyludnienia miast, lecz intensywnie przedtem uprawiane grunty legły odłogiem, przeobrażając się w pastwiska lub, co gorsza, pustynniejąc. Wiele prac naukowych postuluje, że Bliski Wschód, Egipt i Afryka Północna zdołały odzyskać poziom cywilizacyjny sprzed 540 roku dopiero pod koniec XIX wieku. Nadrobienie strat ludnościowych dotyczyło jednak tylko miast, natomiast wieś pozostaje nadal tak samo słabo zaludniona (a jej ziemie w małym stopniu uprawiane), jak piętnaście stuleci wcześniej" (Naphy - Spicer, Czarna śmierć, s. 10-11). Zob. też: S. Sabbatani R. Manfredi-S. Fiorino, The Justinian Plague (Part Two). Influence of the Epidemic on the Rise of the Islamic Empire, „Le Infezioni in Medicina” 20/3 (2012) s. 217-232; M. Meier, The 'Justinianic Plague': The Economic Consequences of the Pandemic in the Eastern Roman Empire and Its Cultural and Religious Effects, „Early Medieval Europe” 24 (2016) s. 267-292. Pełnego przeglądu i oceny artykułów z lat 2000-2018 dotyczących tzw. Plagi Justyniana, jej aspektu medycznego oraz skutków politycznych i ekonomicznych, jak również jej odzwierciedlenia w literaturze dokonali: M. Eisenberg - L. Mordechai, The Justinianic Plague: An interdisciplinary review, „Byzantine and Modern Greek Studies” 43/2 (2019) s. 156-180.

116 Jadwiga Czerwińska podkreśla, iż opis zarazy wpisuje się w stosowaną przez Tukidydesa metodę opisu historycznego, „którego podstawową cechą jest bezstronność relacji i poszukiwanie stałych mechanizmów historii. [...] W przypadku opisu zarazy nasz 
niejszych szczegółów staje się ona wzorem dla innych autorów, którzy opisywali ten atak epidemii bądź inne epidemie pojawiające się w późniejszych wiekach na terenie Europy.

Prokopiusz buduje swoją relację, wzorując się na opisie Tukidydesa, ale raczej na płaszczyźnie struktury poszczególnych jego elementów niż na dosłownym kopiowaniu relacji historyka ateńskiego. Opowiada najpierw o źródłach epidemii, potem o objawach, następnie o zachowaniach ludzkich i zgubnych skutkach choroby zarówno w wymiarze fizycznym (ogromna śmiertelność i zapaść ekonomiczna kraju), jak i psychiczno-moralnym (upadek praw i obyczajów, degeneracja duchowa i etyczna człowieka). Wprowadza do swego opisu więcej dygresji oraz szczegółów dotyczących przemieszczania się epidemii, jej objawów, a nawet zjawisk ,,paranormalnych", częściej też dodaje własne komentarze. Jest to odbiciem zarówno jego indywidualnego stylu pisarstwa, jak i odpowiada gustom czytelników ówczesnej epoki. Jako naoczny świadek rzetelnie przedstawia realia sytuacji, w jakiej się znalazł: objawy choroby przez niego opisane są często dalece odmienne od tych przedstawionych przez Tukidydesa. Wspomina też o tragicznym losie kobiet ciężarnych, a także przedstawia działania, jakie podjęły władze w Bizancjum wobec kompletnej dezorganizacji życia prywatnego i rodzinnego. Więcej miejsca poświęca również skutkom społecznym i politycznym, jakie wywołała zaraza. Niekiedy wyzbywa się też chłodnego obiektywizmu, charakterystycznego dla Tukidydesa, pisząc z pewną dozą złośliwości i goryczy o ludziach niegodziwych, którzy tylko ze strachu zmieniali swoje życie na lepsze, a także o bezczelnych i nikczemnych, którzy uniknęli śmierci, podczas gdy szlachetni i pełni poświęcenia stracili życie.

Obydwaj autorzy, pomimo pesymistycznego spojrzenia na naturę ludzką skłonną bardziej ich zdaniem do występku niż cnoty, zwłaszcza w momencie ogólnospołecznej katastrofy, wojennego zagrożenia czy innego kryzysu, podkreślają również szlachetność i poświęcenie tych, którzy pomimo wyczerpania pielęgnowali chorych: rodziny, przyjaciół i lekarzy, w skutek czego często sami umierali. Chociaż na podstawie scen, jakie malują obydwaj historycy, widać wyraźnie, iż zaraza stała się źródłem patologii

podziw i zdumienie budzi przede wszystkim fakt, że doświadczywszy jej osobiście nie uległ pokusie stworzenia relacji o silnym zabarwieniu emocjonalnym, lecz podążając za ideami jońskiego przyrodoznawstwa - przedstawił zobiektywizowaną prawdę, stając się tym samym prekursorem metodologii naukowej" (J. Czerwińska, Patologia zarazy i patologia wojny w ujęciu Tukidydesa, w: Epidemie, klęski, wojny, red. W. Dzieduszycki J. Wrzesiński, Funeralia Lednickie, Spotkanie 10, Poznań 2008, s. 27). 
społecznej i całkowitej dewaluacji uległy takie pojęcia, jak cnota, dobro, sprawiedliwość czy pobożność, a ludzie w poczuciu ogólnej zagłady zatracili wszelkie hamulce moralne i poczucie przyzwoitości, opisy te jednak odzwierciedlają jednocześnie głęboki tragizm życia ludzi wydanych na pastwę bezlitosnej choroby, złamanych cierpieniami i śmiercią najbliższych, pozbawionych nadziei na ocalenie. Tym szlachetniejsi okazywali się ci, którzy nie wyrzekając się poczucia solidarności z bliźnimi, spieszyli im z pomocą, ryzykując własnym życiem, nawet gdy pomoc ta sprowadzić się mogła tylko do zapewnienia w miarę godnego pochówku.

\title{
Man in the Face of an Epidemic - Thucydides and Procopius of Caesarea
}

\author{
(summary)
}

There is almost one thousand years' time span between two dramatic situations connected with an outbreak of an epidemic described by Thucydides and Procopius of Caesarea. Both authors were eye witnesses to the events they describe, what is more, Thucydides became infected himself, but managed to survive that mysterious disease, which fell on the inhabitants of Attica during the first years of the Peloponnesian War. Procopius, following Thucydides' description, presents most probably the first case of the bubonic plague in Europe, which had a significantly greater impact on the lives of Constantinople's inhabitants as well as of the entire Byzantine Empire not only in the $6^{\text {th }}$ century A.D., but also in the centuries to follow. The description by Thucydides, which is concise and contains specialist medical terminology, provides not only a thorough picture of the very symptoms of that disease, but also depicts before the reader's eyes a variety of human attitudes and behaviours in a situation of extreme threat, when individuals face a continuous risk of losing their own lives and loss of the loved ones in a situation when people do not have any control of the events affecting them. Facing the enormity of the disaster people get prone to reject religious rules and legal norms, which leads to pursuit of immediate profit and pleasure as well as to breaking social ties, abandoning the closest persons to the disease. Thucydides, who remains a pessimist as regards the assessment of human nature, which, according to him, reveals its darkest sides in such extreme situations, does not forget, however, about the individuals who maintained a noble attitude imbued with empathy for those suffering. He stresses the tremendous devotion of the doctors and of those who rush to help not only their relatives, but also friends abandoned while afflicted by misfortune, often sacrificing their own lives. Procopius, while copying Thucydides in the structure and even in some wordings of his description, does not give up by no means the thorough presentation of the reality of the situation in which he found himself. As his account concerns another disease, its symptoms are different, which he meticulously records. He devotes more attention to the actions that have been undertaken in order to get control over the chaos prevailing in the city and organise collecting bodies and burials of the dead; he also mentions the impact of the epidemic on the empire's economy. The same as Thucydides, he focuses on the individual's behaviour in a situation of extreme threat and presents the whole range of attitudes presented by the people beginning from those filled with devotion, risking their lives in order to save other people's lives to those focussed in an egoistic way on pursuit of pleasure and indulgence, breaking the law and 
any religious rules. His comments sometimes show more bitterness or even malice when he says that the disease took away the noblest, most valuable members of society while leaving behind those extremely despicable and wicked.

Keywords: epidemic; Thucydides; Procopius; the Plague of Athens; the Plague of Justinian; man in the situation of extreme threat; breakdown of morality; lawlessness; breakdown of social life; care of the sick; risking one's life

\title{
Człowiek w obliczu epidemii - relacja Tukidydesa i Prokopiusza z Cezarei
}

\author{
(streszczenie)
}

Dwie dramatyczne sytuacje społeczne związane z wybuchem choroby o charakterze epidemicznym, opisane przez Tukidydesa oraz Prokopiusza z Cezarei, oddziela niemal tysiąc lat rozpiętości czasowej. Obydwaj autorzy byli naocznymi świadkami przedstawianych wydarzeń, Tukidydes ponadto sam zaraził się, lecz przeżył tajemniczą chorobę, która spadła na mieszkańców Attyki w pierwszych latach wojny peloponeskiej. Prokopiusz, wzorując się na opisie Tukidydesa, przedstawia najprawdopodobniej pierwszy przypadek dżumy na terenie Europy, która wywarła znacznie większy wpływ na losy mieszkańców Konstantynopola, a także całego imperium bizantyńskiego nie tylko w VI wieku, lecz i w następnych stuleciach. Opis Tukidydesa (zwięzły, z użyciem fachowej terminologii medycznej) dostarcza nie tylko dokładnego obrazu samych objawów tej choroby, lecz także maluje przed oczyma czytelnika różnorodność ludzkich postaw i zachowań w sytuacji skrajnego zagrożenia, w obliczu ciągłego niebezpieczeństwa utraty własnego życia i straty osób najbliższych, kiedy to człowiek nie jest wstanie wywierać jakiegokolwiek wpływu na dotykające go wydarzenia. Tukidydes podkreśla zgubne skutki zarazy, jakie powoduje ona w sferze etycznej i społecznej człowieka. W obliczu ogromu nieszczęścia pojawia się skłonność do odrzucenia zasad religijnych i norm prawnych, co prowadzi do pogoni za szybkim zyskiem i przyjemnością, jak też do zerwania więzi społecznych, pozostawiania bliskich na pastwę choroby. Tukidydes, pozostając pesymistą w ocenie natury ludzkiej, która jego zdaniem właśnie w takich skrajnych sytuacjach ujawnia swe najciemniejsze strony, nie zapomina jednak o osobach, które zachowały postawę szlachetną, pełną współczucia dla cierpiących. Podkreśla ogromne poświęcenie lekarzy oraz tych, którzy śpieszyli z pomocą nie tylko rodzinie, ale i opuszczonym w nieszczęściu przyjaciołom, często płacąc za to własnym życiem. Prokopiusz, naśladując w strukturze, a nawet w niektórych sformułowaniach swego opisu Tukidydesa, nie rezygnuje bynajmniej z rzetelnego przedstawienia realiów sytuacji, w jakiej się znalazł. Ponieważ jego opis dotyczy innej choroby, inne są też objawy, które skrupulatnie relacjonuje. Poświęca więcej miejsca działaniom, jakie podjęto, aby opanować chaos panujący w mieście i zorganizować uprzątanie zwłok oraz pochówki zmarłych, a także wspomina o skutkach, jakie epidemia wywarła w sferze gospodarczej cesarstwa. Podobnie jak Tukidydes skupia swoją uwagę na zachowaniu człowieka w sytuacji skrajnego zagrożenia i prezentuje cały wachlarz ludzkich postaw: od ludzi pełnych poświęcenia ryzykujących własnym życiem, aby ratować innych do osób egoistycznie skupionych na pogoni za przyjemnością i użyciem, łamiących prawo i wszelkie zasady religijne. W jego komentarzach pojawia się niekiedy więcej goryczy, a czasami wręcz złośliwości, gdy mówi, iż choroba zabrała najszlachetniejsze, najbardziej wartościowe jednostki, a pozostawiła przy życiu wyjątkowo podłych i nikczemnych. 
Słowa kluczowe: epidemia; Tukidydes; Prokopiusz; zaraza ateńska; dżuma Justyniana; człowiek w sytuacji skrajnego zagrożenia; upadek obyczajów; bezprawie; rozkład życia społecznego; opieka nad chorymi; ryzykowanie własnym życiem

\section{Bibliografia}

\section{Źródła}

Hippocrates, t. 1-4, tł. W.H.S. Jones - E.T. Withington, Cambridge - London 1923; tł. M. Wesoły, Hippokrates, Wybór pism, t. 1, Biblioteka Antyczna 41, Warszawa 2008. Procopii Caesariensis, Opera omnia, ed. J. Haury, t. 1-3, Bibliotheca Scriptorum Graecorum et Romanorum Teubneriana, Lipsiae 1962-1964, tł. D. Brodka, Prokopiusz, Historia wojen, t. 1: Wojny z Persami i Wandalami, Kraków 2013, t. 2: Wojny z Gotami, Kraków 2015.

Thucydidis Historiae, t. 1, ks. 1-2, red. K. Hude - O. Luschnat, Bibliotheca Scriptorum Graecorum et Romanorum Teubneriana, Lipsiae 1954, tł. K. Kumaniecki, Tukidydes, Wojna peloponeska, Warszawa 1988; Tukidydes, Wojna peloponeska, t. 1, opr. R. Turasiewicz, Wrocław 2004.

Thucydides, Historiae, w: Thucydides, History of the Peloponesian War, tł. CH.F. Smith, London 1956.

\section{Opracowania}

Bornmann F., Motivi tucididei in Procopio, „Atene e Roma: rassegna trimestrale dell'Associazione Italiana di Cultura classica” 19 (1974) s. 138-150.

Bravo B. - Węcowski M. - Wipszycka E. - Wolicki A., Historia Starożytnych Greków, t. 2: Okres Klasyczny, Warszawa 2009.

Bugaj E., Zaraza w świecie rzymskim w czasach Antoninów, w: Epidemie, klęski, wojny, red. W. Dzieduszycki - J. Wrzesiński, Funeralia Lednickie, Spotkanie 10, Poznań 2008, s. 115-123.

Crawfurd R., Plague and Pestilence in Literature and Art, Oxford 1914.

Czerwińska J., Patologia zarazy i patologia wojny w ujęciu Tukidydesa, w: Epidemie, klęski, wojny, red. W. Dzieduszycki - J. Wrzesiński, Funeralia Lednickie, Spotkanie 10, Poznań 2008, s. 25-36.

Duncan Ch. - Scott S., Czarna śmierć. Epidemie w Europie od starożytności do czasów współczesnych, tł. A. Siennicka, Warszawa 2004.

Duncan-Jones, R.P., The Impact of the Antonine Plague, „Journal of Roman Archaeology" 9 (1996) s. 108-136.

Eisenberg M. - Mordechai L., The Justinianic Plague: An interdisciplinary review, „Byzantine and Modern Greek Studies” 43/2 (2019) s. 156-180.

Evans J.A.S., Justynian i Imperium Bizantyńskie, tł. B. Godzińska, Warszawa 2008. 
Evans J.A.S., Justinian and the Historian Procopius, „Greece \& Rome” 17/2 (1970) s. 218-223.

Gomme A.W., A Historical Commentary on Thucydides, t. 2, Oxford 1956.

Jurewicz O., Historia literatury bizantyńskiej. Zarys, Wrocław 1984.

Kaldellis A., Procopius of Caesarea: Tyranny, History and Philosophy at the End of Antiquity, Philadelphia 2004.

Kennnedy S., A Classic Dethroned: The Decline and Fall of Thucydides in Middle Byzantium, „Greek, Roman and Byzantine Studies” 58 (2018) s. 607-635.

Kołodyński J., Zagadkowa przyczyna plagi ateńskiej wyjaśniona!, „Archeologia Żywa” 4 (2006) s. 54-56.

Little L.K., Life and Afterlife of the First Plague Pandemic, w: Plague and the End of Antiquity: The Pandemic of 541-750, red. L.K. Little, Cambridge 2016, s. 3-32.

Littman R.J., The Plague of Athens: Epidemiology and Paleopathology, „Mount Sinai Journal of Medicine" 76/5 (2009) s. 456-467.

Longrigg J., The Great Plague of Athens, „History of Science” 18 (1980) s. 209-225.

Mango C., Historia Bizancjum, tł. M. Dąbrowska, Gdańsk 1997.

Martínez J., Political Consequences of the Plague of Athens, „Graeco-Latina Brunesia” 22/1 (2017) s. 135-146.

McCormick M., The origins of the European economy: Communications and commerce, Cambridge 2001.

Meier M., The 'Justinianic Plague': The Economic Consequences of the Pandemic in the Eastern Roman Empire and Its Cultural and Religious Effects, „Early Medieval Europe" 24 (2016) s. 267-292.

Mitchell S., A History of the Later Roman Empire, AD 284-641, Chichester 2015.

Molenda J., Wyspy greckie. Przewodnik historyczny. Kontrowersyjne dzieje Hellady, Warszawa 2014.

Morens D.M. - Littman R. J., Epidemiology of the Plague of Athens, „Transactions of the Philological Association" 122 (1992) s. 271-304.

Naphy W. - Spicer A., Czarna śmierć, tł. A. Dębska, Warszawa 2004.

Nielsen D.A., Pericles and the Plague: Civil Religion, Anomie, and Injustice in Thucydides, ,Sociology of Religion” 57/4 (1996) s. 397-407.

Nobss A., Digressions in Procopius, w: Le Monde de Procope / The World of Procopius, red. G. Greatrex - S. Janniard, Orient \& Mediterranée 28, Paris 2018, s. 163-171.

Olson P.E. - Hames C.S. - Benenson A.S. - Genovese E.N., The Thucydides Syndrome: Ebola Déjà Vu? (or Ebola Reemergent?), „Emerging Infectious Diseases” 2 (1996) s. 155-156.

Orwin C., Stasis and Plague: Thucydides on the Dissolution of Society, „The Journal of Politics" 50/4 (1988) s. 831-847.

Page D.L., Thucydides'Description of the Great Plague at Athens, „The Classical Quarterly, New Series" 3/4 (1953) s. 97-119. 
Papagrigorakis M.J. - Yapijakis Ch. - Synodinos Ph.N. - Baziotopoulou-Valavani E., DNA examination of ancient dental pulp incriminates typhoid fever as a probable cause of the Plague of Athens, „International Journal of Infectious Diseases” 10 (2006) s. 206-214.

Papanikos G.T., Thucydides and the Synchronous Pandemic, „Athens Journal of History" 7/1 (2021) s. 71-94.

Parry A., The Language of Thucydides'Description of the Plague, „Bulletin of the Institute of Classical Studies of the University of London" 16 (1969) s.106-118.

Sabbatani S. - Manfredi R. - Fiorino S., The Justinian Plague (Part Two). Influence of the Epidemic on the Rise of the Islamic Empire, „Le Infezioni di Medicina” 20/3 (2012) s. 217-232.

Sarris P., The Justinianic Plague: Origins and Effects, „Continuity and Change” 17/2 (2002) s. 169-182.

Shrewsbury J.F.D., The Plague of Athens, „Bulletin of the History of Medicne” 24/1 (1950) s. 1-25.

Stathakopoulos D., Crime and Punishment: The Plague in the Byzantine Empire, 541749, w: Plague and the End of Antiquity: The Pandemic of 541-750, red. L.K. Little, Cambridge 2016, s. 99-118.

Stathakopoulos D., The Justinian Plague revisited, „Byzantine and Modern Greek Studies" 24 (2000) s. 256-276.

Świat Bizancjum, t. 1: Cesarstwo Wschodniorzymskie 330-641, red. C. Morrisson, tł. A. Graboń, Kraków 2007.

Tsiamis C. - Poulakou-Rebelakou E. - Androutsos G., The Role of the Egyptian Sea and Land Routes in the Justinian Plague: The Case of Pelusium, w: Medicine and Healing in the Ancient Mediterranean, red. D. Michaelides Oxford - Philadelphia 2014.

Turasiewicz R., Historiografia: Herodot, Tukidydes, Ksenofont, w: Literatura Grecji starożytnej, t. 2, red. H. Podbielski, Lublin 2005, s. 22-37.

Weidauer K., Thukydides und die Hippokratischen Schriften, Der Einfluss der Medizin auf Zielsetzung und Darstellungsweise des Geschichtswerks, Heilderberg 1954. 